\title{
Spatial and temporal variations of nitrous oxide flux between coastal marsh and the atmosphere in the Yellow River estuary of China
}

\author{
Zhigao Sun • Lingling Wang • Xiaojie Mou • \\ Huanhuan Jiang • Wanlong Sun
}

Received: 14 March 2013 / Accepted: 29 May 2013 /Published online: 21 June 2013

(C) The Author(s) 2013. This article is published with open access at Springerlink.com

\begin{abstract}
To investigate the spatial and seasonal variations of nitrous oxide $\left(\mathrm{N}_{2} \mathrm{O}\right)$ fluxes and understand the key controlling factors, we explored $\mathrm{N}_{2} \mathrm{O}$ fluxes and environmental variables in high marsh (HM), middle marsh (MM), low marsh (LM), and mudflat (MF) in the Yellow River estuary throughout a year. Fluxes of $\mathrm{N}_{2} \mathrm{O}$ differed significantly between sampling periods as well as between sampling positions. During all times of day and the seasons measured, $\mathrm{N}_{2} \mathrm{O}$ fluxes ranged from -0.0051 to $0.0805 \mathrm{mg} \mathrm{N}_{2} \mathrm{O} \mathrm{m}{ }^{-2} \mathrm{~h}^{-1}$, and high $\mathrm{N}_{2} \mathrm{O}$ emissions occurred during spring $\left(0.0278 \mathrm{mg} \mathrm{N} \mathrm{N}_{2} \mathrm{O} \quad \mathrm{m}^{-2} \mathrm{~h}^{-1}\right)$ and winter $\left(0.0139 \mathrm{mg} \mathrm{N}_{2} \mathrm{O} \mathrm{m}^{-2} \mathrm{~h}^{-1}\right)$ while low fluxes were observed during summer $\left(0.0065 \mathrm{mg} \mathrm{N}_{2} \mathrm{O} \mathrm{m}^{-2} \mathrm{~h}^{-1}\right)$ and autumn (0.0060 $\mathrm{mg} \mathrm{N}_{2} \mathrm{O}$ $\mathrm{m}^{-2} \mathrm{~h}^{-1}$ ). The annual average $\mathrm{N}_{2} \mathrm{O}$ flux from the intertidal zone was $0.0117 \mathrm{mg} \mathrm{N}_{2} \mathrm{O} \mathrm{m}^{-2} \mathrm{~h}^{-1}$, and the cumulative $\mathrm{N}_{2} \mathrm{O}$ emission throughout a year was $113.03 \mathrm{mg} \mathrm{N}_{2} \mathrm{O} \mathrm{m}{ }^{-2}$, indicating that coastal marsh acted as $\mathrm{N}_{2} \mathrm{O}$ source. Over all seasons, $\mathrm{N}_{2} \mathrm{O}$ fluxes from the four marshes were significantly different $(p<0.05)$, in the order of $\mathrm{HM}\left(0.0256 \pm 0.0040 \mathrm{mg} \mathrm{N} \mathrm{N}_{2} \mathrm{O} \mathrm{m}{ }^{-2} \mathrm{~h}^{-1}\right)>\mathrm{MF}$
\end{abstract}

Resposible editor: Gerhard Lammel

Z. Sun $(\bowtie) \cdot$ L. Wang $\cdot$ X. Mou $\cdot$ W. Sun

Key Laboratory of Coastal Zone Environmental Processes and Ecological Remediation, Yantai Institute of Coastal Zone Research (YIC), Chinese Academy of Sciences (CAS), Yantai, Shandong 264003, People's Republic of China

e-mail: zgsun@yic.ac.cn

Z. Sun $\cdot$ L. Wang $\cdot$ X. Mou $\cdot$ W. Sun

Shandong Provincial Key Laboratory of Coastal Zone

Environmental Processes, YICCAS, Yantai, Shandong 264003,

People's Republic of China

H. Jiang

Policy Research Center for Environment and Economy,

Ministry of Environmental Protection,

Beijing 100029, People's Republic of China

X. Mou $\cdot$ W. Sun

University of Chinese Academy of Sciences, Beijing 100049,

People's Republic of China $\left(0.0107 \pm 0.0027 \mathrm{mg} \mathrm{N}_{2} \mathrm{O} \mathrm{m} \mathrm{m}^{-2} \mathrm{~h}^{-1}\right)>\mathrm{LM}(0.0073 \pm 0.0020 \mathrm{mg}$ $\left.\mathrm{N}_{2} \mathrm{O} \mathrm{m} \mathrm{m}^{-2} \mathrm{~h}^{-1}\right)>\mathrm{MM}\left(0.0026 \pm 0.0011 \mathrm{mg} \mathrm{N} \mathrm{N}_{2} \mathrm{O} \mathrm{m} \mathrm{m}^{-2} \mathrm{~h}^{-1}\right)$. Temporal variations of $\mathrm{N}_{2} \mathrm{O}$ emissions were related to the vegetations (Suaeda salsa, Phragmites australis, and Tamarix chinensis) and the limited $\mathrm{C}$ and mineral $\mathrm{N}$ in soils during summer and autumn and the frequent freeze/thaw cycles in soils during spring and winter, while spatial variations were mainly affected by tidal fluctuation and plant composition at spatial scale. This study indicated the importance of seasonal $\mathrm{N}_{2} \mathrm{O}$ contributions (particularly during non-growing season) to the estimation of local $\mathrm{N}_{2} \mathrm{O}$ inventory, and highlighted both the large spatial variation of $\mathrm{N}_{2} \mathrm{O}$ fluxes across the coastal marsh $(\mathrm{CV}=158.31 \%)$ and the potential effect of exogenous nitrogen loading to the Yellow River estuary on $\mathrm{N}_{2} \mathrm{O}$ emission should be considered before the annual or local $\mathrm{N}_{2} \mathrm{O}$ inventory was evaluated accurately.

Keywords Nitrous oxide $\left(\mathrm{N}_{2} \mathrm{O}\right) \cdot$ Spatial and temporal variations $\cdot$ Coastal marsh $\cdot$ Yellow River estuary

\section{Introduction}

Nitrous oxide $\left(\mathrm{N}_{2} \mathrm{O}\right)$ is an important greenhouse gas (GHG) that has 298 times the global warming potential of $\mathrm{CO}_{2}$ over a 100-year time period and has been recognized to contribute global warming by $5 \%$ (Mosier 1998). $\mathrm{N}_{2} \mathrm{O}$ has an atmospheric lifetime of 114 years (Mosier 1998) and also contribute to the depletion of ozone in the stratosphere (Crutzen and Ehhalt 1977). The globally averaged atmospheric $\mathrm{N}_{2} \mathrm{O}$ concentration increased from $270 \pm 7 \mathrm{ppb}$ in pre-industrial times (before 1750) to $319 \pm 0.12 \mathrm{ppb}$ in 2005, and is increasing approximately $0.26 \%$ per year (IPCC 2007). In 2010, the globally averaged $\mathrm{N}_{2} \mathrm{O}$ concentration reached $323.2 \mathrm{ppb}$, which exceeded the highest annual mean abundance so far (World Meteorological Organization 2011). Emission of $\mathrm{N}_{2} \mathrm{O}$ from various natural ecosystems has significant influences on global climate change since they account for $44 \sim 54 \%$ of the 
total $\mathrm{N}_{2} \mathrm{O}$ emissions (9.6 10.8 $\mathrm{Tg} \mathrm{N}_{2} \mathrm{O}$ year ${ }^{-1}$ ) (IPCC 2007). Tropical soil and wetlands play an important role in the global nitrogen $(\mathrm{N})$ biogeochemical cycles and are considered significant natural sources of $\mathrm{N}_{2} \mathrm{O}$, contributing approximately $22 \sim 27 \%$ towards this inventory (Whalen 2005).

Coastal marsh is characterized by high temporal and spatial variation involved with topographic feature, environmental factors, and astronomic tidal fluctuation, and is very sensitive to global climate changes and human activities. The intertidal zone between terrestrial and coastal ecosystems may represent a high dynamic interface of intense material processing and transport, with potentially high GHG emission (Hirota et al. 2007). Considerable efforts have been made in the past two decades to quantify the $\mathrm{N}_{2} \mathrm{O}$ fluxes in different coastal ecosystems, especially in estuarine salt marshes (Shingo et al. 2000; Magalhães et al. 2007), mangrove swamps (MuñozHincapié et al. 2002; Allen et al. 2007; Ganguly et al. 2008), coastal lagoons (Gregorich et al. 2006; Hirota et al. 2007), and coastal marshes (Amouroux et al. 2002; Moseman-Valtierra et al. 2011). In China, the studies on $\mathrm{N}_{2} \mathrm{O}$ emission from coastal marshes started quite late and the related research mainly focused on the coastal tundra marshes in Antarctica (Sun et al. 2002; Zhu et al. 2008) and the coastal marshes in the Yangtze River estuary (Yang et al. 2006; Wang et al. 2006, 2007a,b; Wang et al. 2010a) and the Min River estuary (Yang et al. 2012; Mou et al. 2012; Zhang et al. 2012, 2013), while information on the coastal marshes in northern estuaries (such as Liao River estuary and Yellow River estuary) was scarce.

The Yellow River is well-known as a sediment-laden river. Every year, approximately $1.05 \times 10^{7}$ tons of sediment is carried to the estuary and deposited in the slow flowing landform, resulting in vast floodplain and special marsh landscape (Xu et al. 2002; Cui et al. 2009). Sediment deposition is an important process for the formation and development of coastal marshes in the Yellow River Delta. The deposition rate of sediment in the Yellow River not only affects the formation rate of coastal marsh, but also, to some extent, influences the water or salinity gradient and the succession of vegetation from the land to the sea. In recent years, the $\mathrm{N}$ and organic matter (OM) loadings of the Yellow River estuary have significantly increased due to the effects of human activities, and approximately $4.22 \times 10^{4}$ tons of nutrients and $4.39 \times 10^{5}$ tons of OM were discharged into Bohai Sea every year (State Oceanic Administration of China 2013). Increases in N and OM loadings to estuarine and coastal marshes can stimulate microbial processes and associated GHGs emission (Seitzinger and Kroeze 1998; Purvaja and Ramesh 2001). However, information on $\mathrm{N}_{2} \mathrm{O}$ emission from the coastal marsh in the Yellow River estuary is very limited, and the potential effects of exogenous $\mathrm{N}$ loading on $\mathrm{N}_{2} \mathrm{O}$ emission remains poorly discussed.

In this paper, we investigated $\mathrm{N}_{2} \mathrm{O}$ fluxes and environmental variables in the coastal mash of the Yellow River estuary throughout a year (during 2010/2011). The aims of this study are: (1) to determine the spatial and temporal variations of $\mathrm{N}_{2} \mathrm{O}$ fluxes and the annual average $\mathrm{N}_{2} \mathrm{O}$ emission from the coastal marsh, and (2) to investigate the key factors influencing $\mathrm{N}_{2} \mathrm{O}$ variations and assess the potential effects of exogenous $\mathrm{N}$ loading on $\mathrm{N}_{2} \mathrm{O}$ emission.

\section{Materials and methods}

Study site

The study was carried out in the coastal marsh of the Yellow River estuary, which is located in the Nature Reserve of Yellow River Delta $\left(37^{\circ} 35^{\prime} \mathrm{N} \sim 38^{\circ} 12^{\prime} \mathrm{N}, \quad 118^{\circ} 33^{\prime} \mathrm{E} \sim 119^{\circ} 20^{\prime} \mathrm{E}\right)$ in Dongying City, Shandong Province, China. The nature reserve is of typical continental monsoon climate with distinctive seasons. The annual average temperature is $12.1^{\circ} \mathrm{C}$, and the average temperatures in spring, summer, autumn, and winter are 10.7, $27.3,13.1$, and $-5.2{ }^{\circ} \mathrm{C}$, respectively. The temperature changes significantly during early spring and winter, and the freeze/thaw cycles frequently occur in topsoil in majority days, with the frozen depth ranged from 0 to $15 \mathrm{~cm}$. The annual evaporation is $1,962 \mathrm{~mm}$, the annual precipitation is $551.6 \mathrm{~mm}$, with about $70 \%$ of precipitation occurring between June and August.

With an area of $964.8 \mathrm{~km}^{2}$, coastal marsh is the main type of marsh in the Yellow River Delta and accounts for $63.06 \%$ of total area (Cui et al. 2009). In the intertidal zone, natural geomorphology and depositing zones are distinct, and high marsh (HM), middle marsh (MM), low marsh (LM), and mudflat (MF) develop from the land to the sea. The soil in the intertidal zone is dominated by salt soil. Suaeda salsa, an annual $\mathrm{C}_{3}$ plant, is the most prevalent halophytes in the coastal marshes of the Yellow River estuary (Tian et al. 2005). Due to the differences of water and salinity conditions, three $S$. salsa phenotypes are generally formed in HM, MM, and LM, respectively. The HM is predominated by $S$. salsa $(>90 \%)$ and Phragmites australis $(<10 \%)$, MM is predominated by S. salsa ( $>95 \%)$ and Tamarix chinensis $(<5 \%)$, while LM is pure $S$. salsa community (100\%) (Mou 2010). The tide in the intertidal zone of the Yellow River estuary is irregular semidiurnal tide (twice a day) and the mean tidal range is $0.73 \sim 1.77 \mathrm{~m}$ (Li et al. 1991).

\section{Experimental design}

Four sampling positrons were laid in HM, MM, LM, and MF in the intertidal zone of the Yellow River estuary. $\mathrm{N}_{2} \mathrm{O}$ fluxes across the sediment-atmosphere interface were measured by using opaque, static, manual stainless steel chambers, and gas chromatography techniques. The chamber $(50 \times 50 \times 50 \mathrm{~cm})$ and its base $(50 \times 50 \times 20 \mathrm{~cm})$ were made from $0.4-\mathrm{mm}$ thickness stainless steel. Inside the chamber, an electric fan was fixed to stir the air, a thermometer sensor was installed to 
measure temperature, a trinal-venthole was fixed to collect gas sample, and a balance pipe was used to equalize the air pressure between the inside and the outside of the chamber. Outside of the chamber was covered with $2 \mathrm{~cm}$ thickness white foam to reduce the impact of direct radiative heating during sampling, which generally caused very little change in temperature between the inside and the outside of the chamber (Teiter and Mander 2005; SØvik and KlØve 2007; Song et al. 2008; Jiang et al. 2010). All the connections were made "air tight" and sealed by silicon rubber. The stainless steel bases enclosed an area of $0.25 \mathrm{~m}^{2}$ and were inserted into the ground to a depth of $20 \mathrm{~cm}$ below the soil on August 2010. During observations, the chamber was placed over the base filled with water in the groove to prevent leakage, and the plant was covered within the chamber.

Sampling campaigns were undertaken in September, October, November, and December in 2010, and April, May, June, and July in 2011 (the sampling in January, February, and March were canceled due to the frequent effects of storm tide and bad weather and that in August was canceled due to the damage of most chambers and instruments). Each measurement campaign consisted of 12 chambers set up at above-mentioned four positions (three chambers per site). On each sampling date, measurements were conducted at 0700, 0930, 1200, 1430, and 1700 hours (represented different times of day). About $60 \mathrm{ml}$ gas sample inside the chamber was collected every $20 \mathrm{~min}$ over a 60 -min period by using 100-ml syringe (total of four samples), and then stored in pre-evacuated gas sampling bags $(100 \mathrm{ml})$. Since the tide in the Yellow River estuary is irregular semidiurnal tide, the sampling campaigns in the LM and MF were sometimes affected by tidal inundation. The sampling campaigns in the LM and MF in May and the MF in June were not carried out due to the great influence of tide.

$\mathrm{N}_{2} \mathrm{O}$ concentrations of gas samples were analyzed within $36 \mathrm{~h}$ using gas chromatography (Agilent 7890A) equipped with ECD. The $\mathrm{N}_{2} \mathrm{O}$ portion was separated using a $1-\mathrm{m}$ stainless steel column with an inner diameter 2-mm Porapak Q (80/100 mesh), and was measured using the ECD, which was set at $330{ }^{\circ} \mathrm{C}$. The ECD also used high-pure nitrogen as a carrier gas, a flow rate of $35 \mathrm{ml} \mathrm{min}^{-1}$. The column temperatures were maintained at $55{ }^{\circ} \mathrm{C}$ for all separations. Gas concentrations were quantified by comparing peak areas of samples against standards run every eight samples, ensuring each sample run maintained RSD below $6 \%$.

$\mathrm{N}_{2} \mathrm{O}$ fluxes were calculated according to the following equation:

$J=\frac{d c}{d t} \times \frac{M}{V_{0}} \times \frac{P}{P_{0}} \times \frac{T_{0}}{T} \times H$

where $d c / d t$ is the slope of the gas concentration curve variation along with time. $M$ is the mole mass of each gas.
$P$ is the atmospheric pressure in the sampling site. $T$ is the absolute temperature during sampling. $V_{0}, T_{0}, P_{0}$ are the gas mole volume, air absolute temperature, and atmospheric pressure under standard conditions, respectively. $H$ is the height of chamber above the ground/water surface.

The annual average $\mathrm{N}_{2} \mathrm{O}$ flux was calculated by the data determined in the eight sampling months (covered four seasons). The $\mathrm{N}_{2} \mathrm{O}$ emission/absorption (milligram of $\mathrm{N}_{2} \mathrm{O}$ per meter squared) per sampling month was calculated by the average value (milligram of $\mathrm{N}_{2} \mathrm{O}$ per meter squared per hour) of all sampling data and the time (hour) in each month. The $\mathrm{N}_{2} \mathrm{O}$ emissions/absorptions in January and February were estimated by the average value in winter (December), and those in March and August were estimated by the average values determined in spring (April and May) and summer (June and July), respectively. The cumulative $\mathrm{N}_{2} \mathrm{O}$ emissio$\mathrm{n} / \mathrm{absorption}$ throughout a year was estimated by the values in 12 months.

\section{Environmental measurements}

Air temperature and soil temperatures $(0,5,10$, and $15 \mathrm{~cm})$ were measured in each position during gas sampling. Soil volumetric moisture and electrical conductivity (EC) in $0-5$ and $5-10 \mathrm{~cm}$ depths were determined in situ by highprecision moisture measuring instrument (AZS-2) and soil and solution EC meter (Field Scout), respectively. Soil moisture and EC were not determined in December 2010 since the topsoil was frozen. Because the measurements in LM and MF in September 2010 were partly and slightly affected by tide (from 1200 to 1700 hours), the flooding depths were measured to discuss the effects of tidal inundation on $\mathrm{N}_{2} \mathrm{O}$ emission. On each sampling date, two soil samples per layer $(0-10,10-20 \mathrm{~cm})$ were taken in each site for analyzing TC and TN contents by element analyzer (Elementar Vario Micro, German) and $\mathrm{NH}_{4}{ }^{+}-\mathrm{N}$ and $\mathrm{NO}_{3}{ }^{-}-\mathrm{N}$ contents by sequence flow analyzer ( $\mathrm{San}^{++}$SKALAR, Netherlands).

\section{Statistical analysis}

The Shapiro-Wilk test was applied to identify the normality of data before the related statistical analyses were conducted. The results were presented as means of the replications, with standard error. Statistical significance of differences at $p<0.05$ between samples was analyzed using analysis of variance (ANOVA). Multiple comparison of samples was undertaken by Tukey's test with a significance level of $p=0.05$. Correlation analyses and stepwise linear regression analyses were used to examine the relationship between fluxes and the measured environmental variables. In all tests, differences were considered significantly only if $p<0.05$. 


\section{Results}

Environmental variables in coastal marsh

Similar variations of air temperature and ground temperature in the four marshes were observed over all sampling period (Fig.1a). Air temperature did not show significant difference among the four marshes $(p>0.05)$ and the means were $19.69,17.90,15.74$, and $15.00{ }^{\circ} \mathrm{C}$, respectively. Ground temperatures generally decreased with increasing soil depth, but no significant differences were found within the four marshes $(p>0.05)$. Dissimilar variations of soil moisture and EC in the four marshes were observed (Fig.1b, c). With increasing depth, soil moisture increased while EC generally decreased. Soil moisture did not show significant differences among the four marshes $(p>0.05)$, while significant differences of EC were observed $(p<0.05)$. Seasonal dynamics of soil substrate in the four marshes were observed over all sampling period (Fig. 2). TC, $\mathrm{TN}$, and $\mathrm{NH}_{4}{ }^{+}-\mathrm{N}$ in the surface and subsurface soil of MF were generally higher than those in other marshes (Fig. $2 \mathrm{a}-\mathrm{c})$. Both TC in surface and subsurface soil had significant differences within the four marshes $(p<0.05)$, while only $\mathrm{TN}$ in subsurface soil showed significant difference $(p<0.01)$. Both $\mathrm{NH}_{4}{ }^{+}-\mathrm{N}$ and $\mathrm{NO}_{3}{ }^{-}-\mathrm{N}$ in soil were not significantly different among the four marshes $(p>0.05)$.

Spatial variations of $\mathrm{N}_{2} \mathrm{O}$ fluxes

\section{Variation of $\mathrm{N}_{2} \mathrm{O}$ fluxes in spring}

$\mathrm{N}_{2} \mathrm{O}$ fluxes in spring averaged between -0.0102 and $0.0982 \mathrm{mg} \mathrm{N}_{2} \mathrm{O} \mathrm{m} \mathrm{m}^{-2} \mathrm{~h}^{-1}$ and differed significantly among the four marshes $(p<0.01)$ (Fig. 3). With the exception of $\mathrm{MM}$, the other sites were found to release $\mathrm{N}_{2} \mathrm{O}$ during all times of day sampled. In $\mathrm{HM}, \mathrm{N}_{2} \mathrm{O}$ fluxes in April and May were similar except for 1700 hours sampling, and significantly higher emission occurred in April compared to May $(p<0.01) . \mathrm{N}_{2} \mathrm{O}$ fluxes from $\mathrm{MM}$ in April and May were opposite except for 1200 hours sampling, and the ranges were $-0.0065 \sim 0.0131$ and $-0.0102 \sim 0.0081 \mathrm{mg} \quad \mathrm{N}_{2} \mathrm{O}$ $\mathrm{m}^{-2} \mathrm{~h}^{-1}$, respectively. $\mathrm{N}_{2} \mathrm{O}$ fluxes from LM in April had no significant variation before 1430 hours and a significant peak occurred in 1700 hours. In $\mathrm{MF}, \mathrm{N}_{2} \mathrm{O}$ fluxes in April ranged from 0.0285 to $0.0512 \mathrm{mg} \mathrm{N}_{2} \mathrm{O} \mathrm{m} \mathrm{m}^{-2} \mathrm{~h}^{-1}$ and the maximum occurred in 1200 hours. The mean $\mathrm{N}_{2} \mathrm{O}$ fluxes from HM, MM, LM, and $\mathrm{MF}$ in spring were $0.0582,0.0026,0.0069$, and $0.0384 \mathrm{mg} \mathrm{N}_{2} \mathrm{O} \mathrm{m} \mathrm{m}^{-2} \mathrm{~h}^{-1}$, and the cumulative $\mathrm{N}_{2} \mathrm{O}$ emissions were 128.02, 5.75, 15.19 , and $84.74 \mathrm{mg} \mathrm{N}_{2} \mathrm{O} \mathrm{m} \mathrm{m}^{-2}$, respectively, indicating that coastal marsh represented $\mathrm{N}_{2} \mathrm{O}$ source.
Variation of $\mathrm{N}_{2} \mathrm{O}$ fluxes in summer

$\mathrm{N}_{2} \mathrm{O}$ fluxes in summer ranged from -0.0147 to $0.0262 \mathrm{mg}$ $\mathrm{N}_{2} \mathrm{O} \mathrm{m} \mathrm{m}^{-2} \mathrm{~h}^{-1}$ and differed significantly among the four marshes in June $(p<0.05)$ (Fig. 3). With the exception of $\mathrm{HM}$ that were found to release $\mathrm{N}_{2} \mathrm{O}$ during all times of day sampled, the other sites showed consumptions in some sampling times. $\mathrm{N}_{2} \mathrm{O}$ fluxes from HM in June and July were $0.0085 \sim 0.0262$ and $0.0117 \sim 0.0206 \mathrm{mg} \mathrm{N}_{2} \mathrm{O} \mathrm{m}^{-2} \mathrm{~h}^{-1}$, respectively, and no significant difference was found between them $(p>0.05)$. In MM, $\mathrm{N}_{2} \mathrm{O}$ fluxes in June and July were significantly different $(p<0.05)$ and the means were -0.0051 and $0.0052 \mathrm{mg} \mathrm{N}_{2} \mathrm{O} \mathrm{m}^{-2} \mathrm{~h}^{-1}$, respectively. Although $\mathrm{N}_{2} \mathrm{O}$ fluxes from LM in June and July were opposite except for 1430hours sampling, they had no significant difference $(p>0.05)$. The MF was found to release $\mathrm{N}_{2} \mathrm{O}$ before July 1430 hours sampling and significant consumption occurred in 1700hours. The average $\mathrm{N}_{2} \mathrm{O}$ fluxes from HM, MM, LM, and $\mathrm{MF}$ in summer were 0.0165, 0.00002, 0.0035, and $0.0055 \mathrm{mg} \mathrm{N}_{2} \mathrm{O} \mathrm{m}^{-2} \mathrm{~h}^{-1}$, and the cumulative $\mathrm{N}_{2} \mathrm{O}$ emissions were $36.54,0.17,7.92$, and $12.14 \mathrm{mg} \mathrm{N}_{2} \mathrm{O} \mathrm{m}^{-2}$, respectively, indicating that coastal marsh acted as weak $\mathrm{N}_{2} \mathrm{O}$ source.

\section{Variation of $\mathrm{N}_{2} \mathrm{O}$ fluxes in autumn}

$\mathrm{N}_{2} \mathrm{O}$ fluxes in autumn averaged between -0.0092 and $0.0312 \mathrm{mg} \mathrm{N}_{2} \mathrm{O} \mathrm{m}^{-2} \mathrm{~h}^{-1}$ and differed significantly among the four marshes in October $(p<0.01)$ (Fig. 3). In HM, with the exception of September 0700 hours sampling, the other times were found to release $\mathrm{N}_{2} \mathrm{O}$. Significantly higher emission occurred in October compared to September and November $(p<0.01) . \mathrm{N}_{2} \mathrm{O}$ fluxes from $\mathrm{MM}$ in autumn showed both emission and consumption, but no significant difference was found among sampling periods $(p>0.05)$. $\mathrm{N}_{2} \mathrm{O}$ fluxes from LM in September and October were opposite except for 0700 and 0930 hours sampling. $\mathrm{N}_{2} \mathrm{O}$ fluxes from MF in September and November were similar, but they had significant difference $(p<0.01)$. The LM in November and $\mathrm{MF}$ in October were found to release $\mathrm{N}_{2} \mathrm{O}$ over all sampling times, with the maximums occurred in 1200 and 0700 hours, respectively. The mean $\mathrm{N}_{2} \mathrm{O}$ fluxes from $\mathrm{HM}$, MM, LM, and MF in autumn were 0.0118, 0.0031, 0.0038, and $0.0053 \mathrm{mg} \mathrm{N}_{2} \mathrm{O} \mathrm{m} \mathrm{m}^{-2} \mathrm{~h}^{-1}$, and the cumulative $\mathrm{N}_{2} \mathrm{O}$ emissions were $26.01,6.90,8.16$, and $11.70 \mathrm{mg} \mathrm{N}_{2} \mathrm{O} \mathrm{m}^{-2}$, respectively, indicating that coastal marsh represented weak $\mathrm{N}_{2} \mathrm{O}$ source.

\section{Variation of $\mathrm{N}_{2} \mathrm{O}$ fluxes in winter}

$\mathrm{N}_{2} \mathrm{O}$ fluxes in winter ranged from -0.0114 to $0.0442 \mathrm{mg}$ $\mathrm{N}_{2} \mathrm{O} \mathrm{m} \mathrm{m}^{-2} \mathrm{~h}^{-1}$ and differed significantly among the four marshes $(p<0.01)$ (Fig. 3). The average $\mathrm{N}_{2} \mathrm{O}$ fluxes from HM, MM, LM, and MF were 0.0195, 0.0059, 0.0257, and 

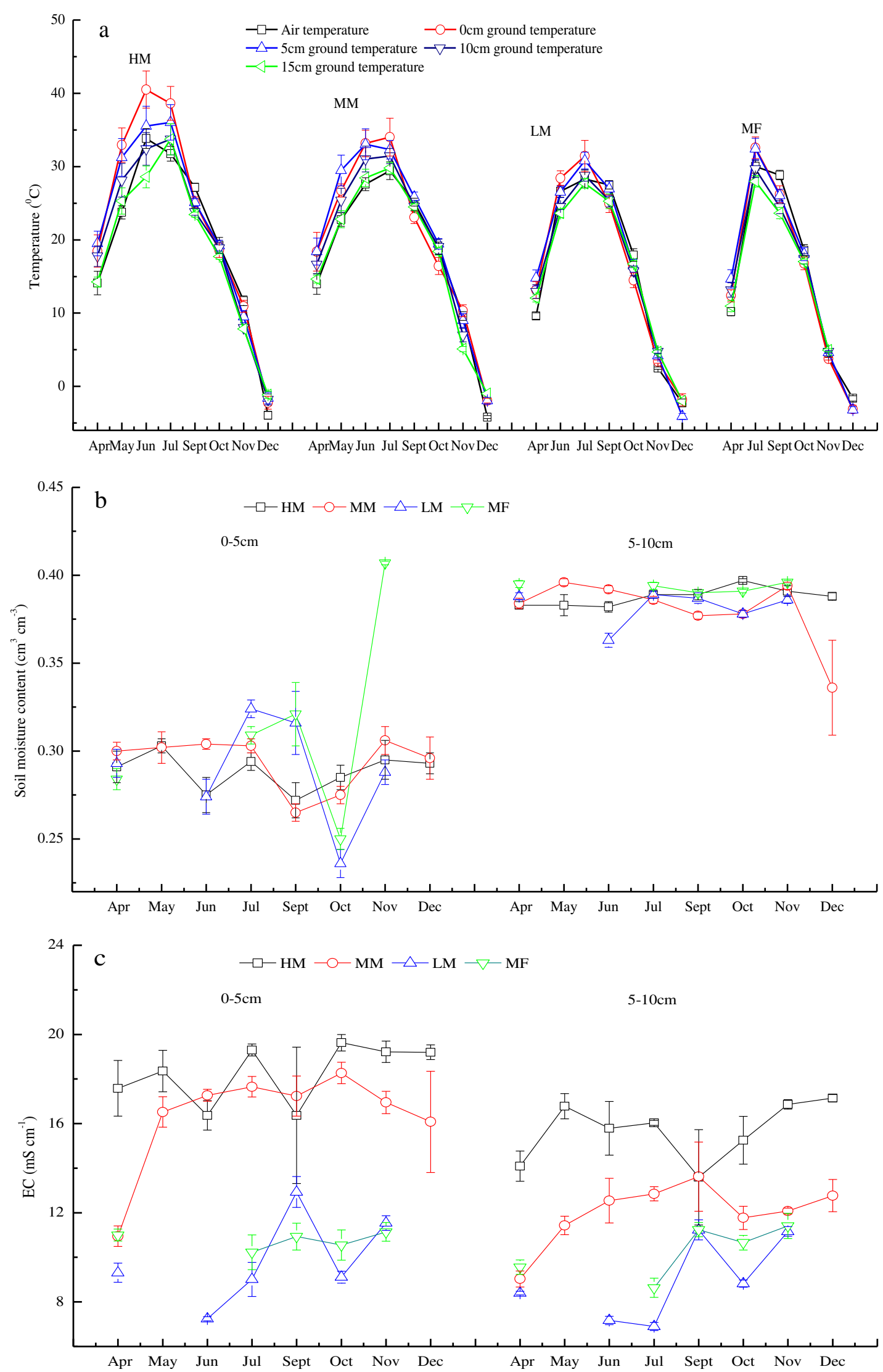

Fig. 1 Variations of environmental temperatures (a), soil moisture content (b), and electrical conductivity $(E C)(\mathbf{c})$ in high marsh $(H M)$, middle marsh $(M M)$, low marsh $(L M)$, and mudflat $(M F)$ 

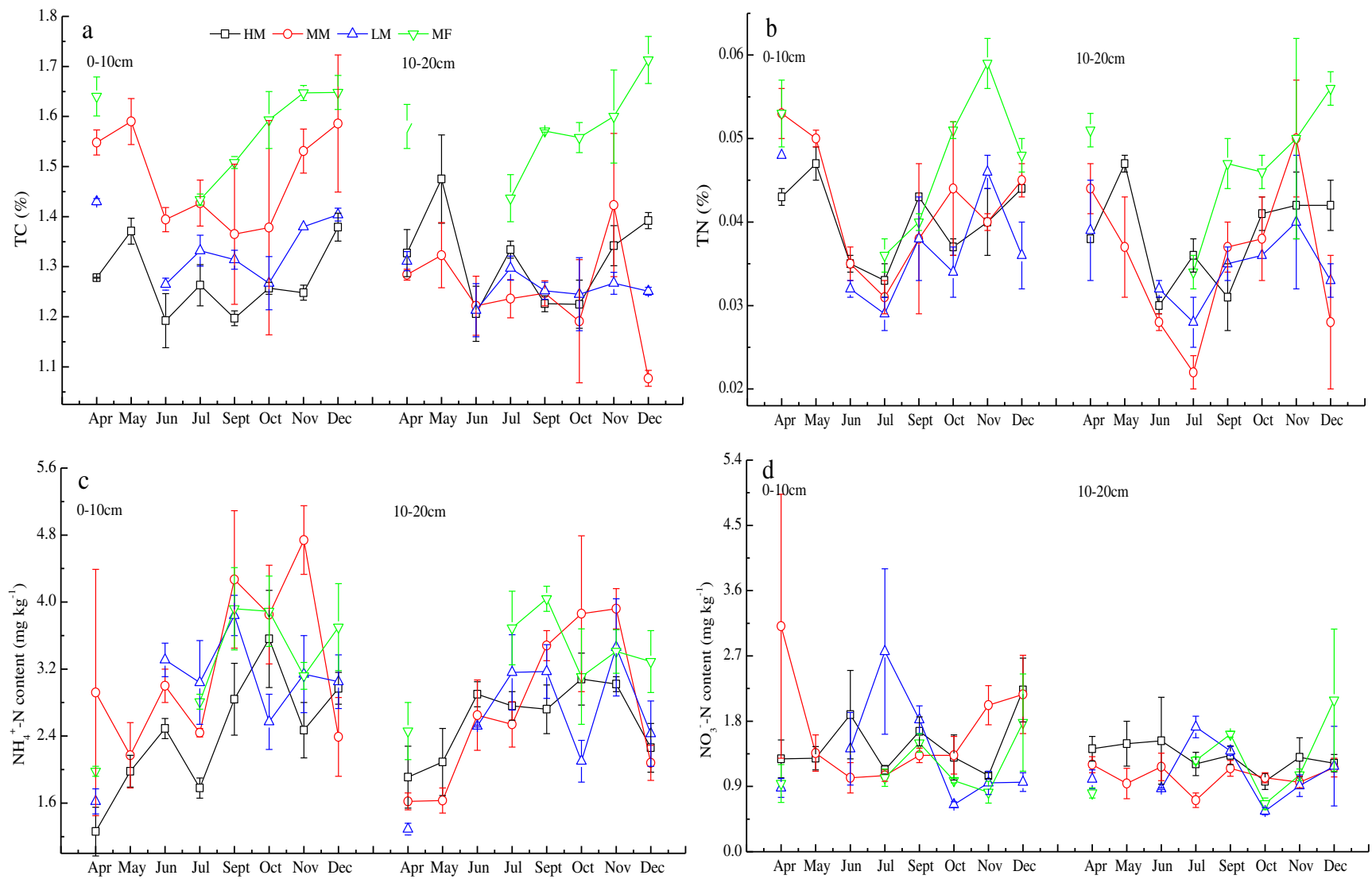

Fig. 2 Variations of TC (a), $\mathrm{TN}(\mathbf{b}), \mathrm{NH}_{4}{ }^{+}-\mathrm{N}(\mathbf{c})$, and $\mathrm{NO}_{3}{ }^{-}-\mathrm{N}(\mathbf{d})$ contents in high marsh $(H M)$, middle marsh $(M M)$, low marsh $(L M)$, and mudflat $(M F)$ soils

$0.0047 \mathrm{mg} \mathrm{N}_{2} \mathrm{O} \mathrm{m}^{-2} \mathrm{~h}^{-1}$, and the cumulative $\mathrm{N}_{2} \mathrm{O}$ emissions were $42.12,12.79,55.47$, and $10.11 \mathrm{mg} \mathrm{N}_{2} \mathrm{O} \mathrm{m}^{-2}$, respectively, indicating that coastal marsh acted as $\mathrm{N}_{2} \mathrm{O}$ source. Significantly higher emissions were observed in HM and LM compared to MM and MF during all times of day sampled $(p<0.05)$.

Temporal variations of $\mathrm{N}_{2} \mathrm{O}$ fluxes

Significant temporal variations of $\mathrm{N}_{2} \mathrm{O}$ fluxes throughout a year were observed in HM, LM, and MF ( $p<0.01)$ (Fig. 4). During all times of day and the seasons measured, $\mathrm{N}_{2} \mathrm{O}$ fluxes from the intertidal zone averaged between -0.0051 and $0.0805 \mathrm{mg} \mathrm{N}_{2} \mathrm{O}$ $\mathrm{m}^{-2} \mathrm{~h}^{-1}$, and the annual average $\mathrm{N}_{2} \mathrm{O}$ flux was $0.0117 \mathrm{mg} \mathrm{N} \mathrm{N}_{2} \mathrm{O}$ $\mathrm{m}^{-2} \mathrm{~h}^{-1}$. The maximum and minimum were observed in April (in $\mathrm{HM}$ ) and June (in MM), respectively. High $\mathrm{N}_{2} \mathrm{O}$ emissions generally occurred during spring $\left(0.0278 \mathrm{mg} \mathrm{N}_{2} \mathrm{O} \mathrm{m}^{-2} \mathrm{~h}^{-1}\right)$ and winter $\left(0.0139 \mathrm{mg} \mathrm{N}_{2} \mathrm{O} \mathrm{m}^{-2} \mathrm{~h}^{-1}\right)$ while low fluxes were observed during summer $\left(0.0065 \mathrm{mg} \mathrm{N}_{2} \mathrm{O} \mathrm{m}^{-2} \mathrm{~h}^{-1}\right)$ and autumn (0.0060 mg $\mathrm{N}_{2} \mathrm{O} \mathrm{m} \mathrm{m}^{-2} \mathrm{~h}^{-1}$ ) (Fig. 4). Over all seasons, $\mathrm{N}_{2} \mathrm{O}$ fluxes from the four marshes were significantly different $(p<0.05)$, in the order of $\mathrm{HM}\left(0.0256 \pm 0.0040 \mathrm{mg} \mathrm{N} \mathrm{N}_{2} \mathrm{O}\right.$
Fig. 3 Spatial variations of $\mathrm{N}_{2} \mathrm{O}$ fluxes (milligram of $\mathrm{N}_{2} \mathrm{O}$ per meter squared per hour) from high marsh $(H M)$, middle marsh $(M M)$, low marsh $(L M)$, and mudflat $(M F)$ in spring (April and May), summer (June and July), autumn (September, October, and November), and winter (December)

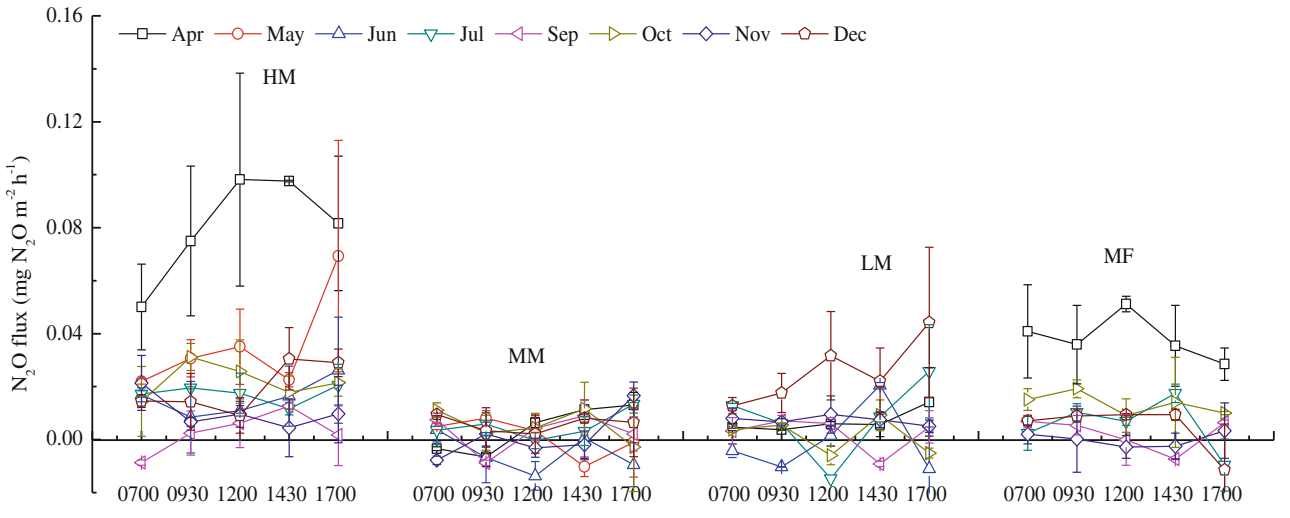


Fig. 4 Temporal variations of $\mathrm{N}_{2} \mathrm{O}$ fluxes (milligram of $\mathrm{N}_{2} \mathrm{O}$ per meter squared per hour) from high marsh $(H M)$, middle marsh $(M M)$, low marsh $(L M)$, and mudflat $(M F)$. Bars with different letters $(a, b, c, d$ for $H M ; x, y$ for $M M ; m, n$ for $L M$; $o, p, q$ for $M F$ ) are significantly different at the level of $p<0.05$; bars with same letters are not significantly different at the level of $p<0.05$

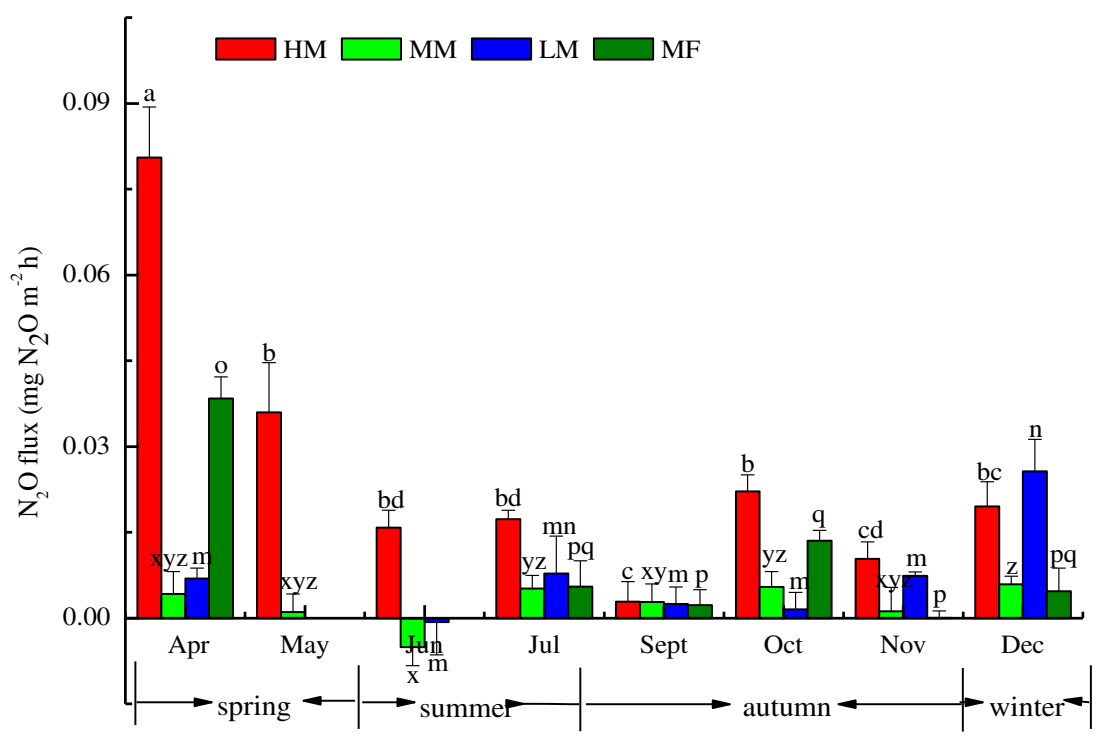

$\left.\mathrm{m}^{-2} \mathrm{~h}^{-1}\right)>\mathrm{MF}\left(0.0107 \pm 0.0027 \mathrm{mg} \mathrm{N}_{2} \mathrm{O} \mathrm{m} \mathrm{m}^{-2} \mathrm{~h}^{-1}\right)>\mathrm{LM}$ $\left(0.0073 \pm 0.0020 \mathrm{mg} \mathrm{N}_{2} \mathrm{O} \mathrm{m}^{-2} \mathrm{~h}^{-1}\right)>\mathrm{MM}$ $\left(0.0026 \pm 0.0011 \mathrm{mg} \mathrm{N}_{2} \mathrm{O} \mathrm{m} \mathrm{m}^{-2} \mathrm{~h}^{-1}\right)$. The cumulative $\mathrm{N}_{2} \mathrm{O}$ emission from the intertidal zone throughout a year was $113.03 \mathrm{mg} \mathrm{N}_{2} \mathrm{O} \mathrm{m} \mathrm{m}^{-2}$, indicating that coastal marsh acted as $\mathrm{N}_{2} \mathrm{O}$ source. Comparatively, the $\mathrm{N}_{2} \mathrm{O}$ emissions measured during spring and winter contributed 49.65 and $26.65 \%$ of the total emission, respectively, which were higher than the contributions measured during summer $(12.03 \%)$ and autumn (11.67\%).

\section{Relationships between environmental variables and $\mathrm{N}_{2} \mathrm{O}$ fluxes}

Most correlations between $\mathrm{N}_{2} \mathrm{O}$ fluxes and temperatures in different marshes were not significant $(p>0.05$; Table 1). Although both positive and negative impacts of soil moisture (or EC) on $\mathrm{N}_{2} \mathrm{O}$ emissions were observed within the four marshes, only the correlation between soil moisture $(5-10 \mathrm{~cm})$ and $\mathrm{N}_{2} \mathrm{O}$ fluxes in LM was significant ( $p<0.05$; Table 2$)$. Lacks of correlations between $\mathrm{N}_{2} \mathrm{O}$ fluxes and substrate variables were observed $(p>0.05)$ except the correlations occurred in subsurface soil of HM and MF $(p<0.05$; Table 3$)$. The environmental variables determined in the four coastal marshes were all excluded in the stepwise liner regression. $\mathrm{NH}_{4}{ }^{+}-\mathrm{N}$ content $\left(X_{1}\right)$ and $\mathrm{TC}$ content $\left(X_{2}\right)$ were the dominant factors that controlled the $\mathrm{N}_{2} \mathrm{O}$ emissions $(Y)$ in HM $\left(Y=0.129-0.040 X_{1}, R^{2}=0.539, p=0.038\right)$ and LM $\left(Y=-0.109+0.090 X_{2}, R^{2}=0.798, p=0.016\right)$, respectively, while in $\mathrm{MM}$ and $\mathrm{MF}$, the environmental variables determined during sampling periods were all excluded, indicating that $\mathrm{N}_{2} \mathrm{O}$ fluxes were controlled by multiple site-specific factors.

\section{Discussion}

Temporal variations of $\mathrm{N}_{2} \mathrm{O}$ fluxes

Many studies have demonstrated that the seasonal patterns of $\mathrm{N}_{2} \mathrm{O}$ fluxes were generally governed by seasonal variability in temperatures since it influenced water availability, production of substrate precursors, and microbial activity (Whalen 2005; Zhu et al. 2008). However, we have drawn a different result. Although significant temporal variations in $\mathrm{N}_{2} \mathrm{O}$ fluxes from the coastal marshes in the Yellow River estuary were observed, the influence of seasonal variability in temperatures on $\mathrm{N}_{2} \mathrm{O}$ emissions seemed not significant (Figs. 1a and 4). Moreover, most correlations between $\mathrm{N}_{2} \mathrm{O}$ fluxes and temperatures in different marshes were not significant $(p>0.05)$ (Table 1). These indicated that the influences of temperatures on $\mathrm{N}_{2} \mathrm{O}$ emissions might be covered by other biotic/abiotic parameters (such as vegetation, soil moisture, and substrate) in most sampling periods. Because the environmental variables determined in coastal marsh were all excluded in the stepwise liner regression, we considered that $\mathrm{N}_{2} \mathrm{O}$ emissions in different seasons might be controlled by the interactions of multiple controlling factors.

In this paper, we observed that $\mathrm{N}_{2} \mathrm{O}$ emissions in spring, summer, autumn, and winter were 0.0278, 0.0065, 0.0060, and $0.0139 \mathrm{mg} \mathrm{N}_{2} \mathrm{O} \mathrm{m}^{-2} \mathrm{~h}^{-1}$, respectively (Fig. 4), and low values occurred during summer and autumn. The result was similar with Allen et al. (2007) but was different with Wang et al. (2007a) and Søvik and Kløve (2007). There were two possible reasons. Firstly, the presence of vegetations $(P$. australis, $S$. salsa, and T. chinensis) across the coastal marsh might have significant effects on the low $\mathrm{N}_{2} \mathrm{O}$ emissions during the growing season. Many studies have demonstrated that, under flooding or anaerobic conditions, the three mash 


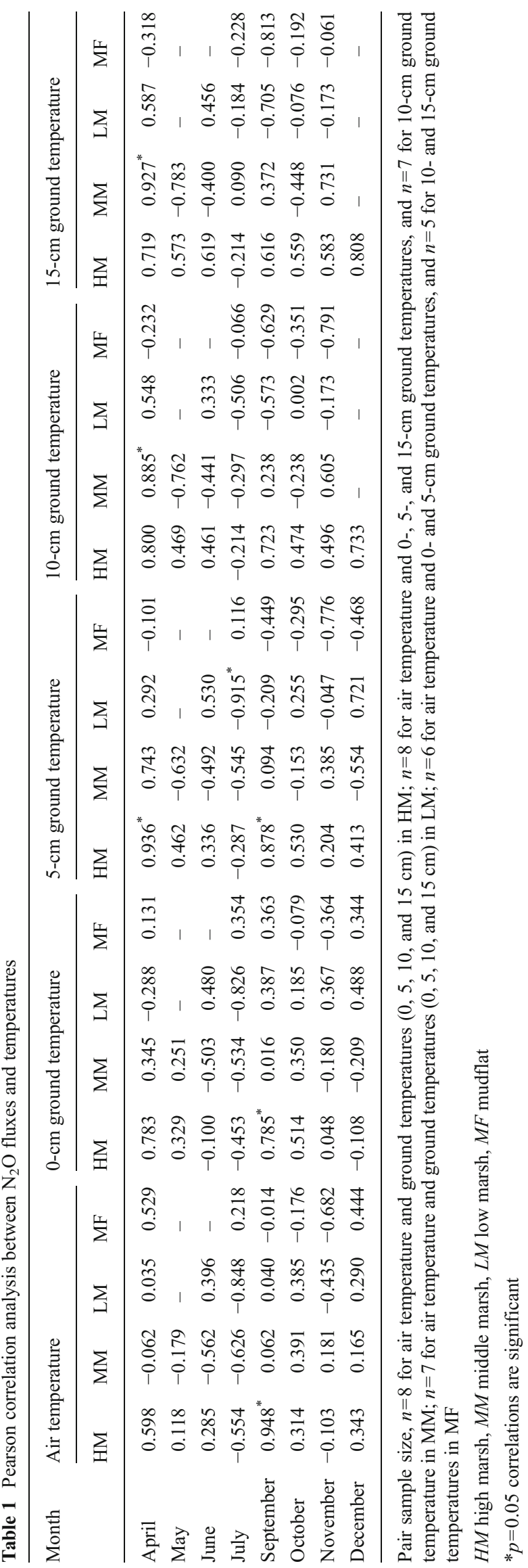

Table 2 Pearson correlation analysis between $\mathrm{N}_{2} \mathrm{O}$ fluxes and soil moisture or electrical conductivity (EC)

\begin{tabular}{lccllc}
\hline Sites & \multicolumn{2}{l}{ Soil moisture } & & \multicolumn{2}{l}{ Electrical conductivity (EC) } \\
\cline { 2 - 3 } \cline { 5 - 6 } & $0-5 \mathrm{~cm}$ & $5-10 \mathrm{~cm}$ & & $0-5 \mathrm{~cm}$ & $5-10 \mathrm{~cm}$ \\
\hline $\mathrm{HM}$ & 0.296 & -0.419 & & -0.053 & -0.321 \\
$\mathrm{MM}$ & -0.382 & -0.532 & & -0.192 & -0.049 \\
LM & 0.577 & $0.839^{*}$ & & 0.329 & 0.135 \\
MF & -0.605 & 0.165 & & 0.153 & -0.407 \\
\hline
\end{tabular}

Pair sample size, $n=8$ for soil moisture and EC in $0-5$ and $5-10 \mathrm{~cm}$ depths in HM and MM; $n=6$ for soil moisture and EC in $0-5$ and 5$10 \mathrm{~cm}$ depths in LM; $n=5$ for soil moisture and EC in $0-5$ and $5-10 \mathrm{~cm}$ depths in MF

$H M$ high marsh, $M M$ middle marsh, $L M$ low marsh, $M F$ mudflat

${ }^{*} p=0.05$ correlations are significant

plants could transport oxygen from aboveground parts to roots by aerenchyma (Han et al. 2005; Ling et al. 2008; Kong et al. 2008; Ge and Zhang 2011), which generally formed oxidizing microenvironment around rhizosphere soil (Kong et al. 2008). Moreover, the roots of the three plants could excrete some small molecular compounds (glucide, organic acid, and amion acid), which caused the microorganism amount and microbial activity in rhizosphere soil to be much higher than those in non-rhizosphere soil (Ling et al. 2008; Cheng 2009; Wang et al. 2010b; Ge and Zhang 2011). These indicated that although the coastal marshes were frequently influenced by tidal inundation, the nitrification-denitrification rate still could be accelerated by the three plants since the soil microbes in rhizosphere were generally supplied with available $\mathrm{C}$ and $\mathrm{N}$ and proper amount of oxygen. Thus, $\mathrm{N}_{2} \mathrm{O}$, to a great extent, was reduced to $\mathrm{N}_{2}$ by denitrification regardless of whether $\mathrm{N}_{2} \mathrm{O}$ was produced by nitrification or denitrification or both, which resulted in the great decrease of $\mathrm{N}_{2} \mathrm{O}$ emissions. Secondly, as mentioned before, $\mathrm{N}_{2} \mathrm{O}$ production was through nitrification and denitrification, in which microorganism used the $\mathrm{C}$ and mineral $\mathrm{N}\left(\mathrm{NH}_{4}{ }^{+}-\mathrm{N}\right.$ and $\left.\mathrm{NO}_{3}{ }^{-}-\mathrm{N}\right)$ as substrates (Conrad 1996). The low $\mathrm{N}_{2} \mathrm{O}$ emissions in summer might also be due to the limited $\mathrm{C}$ and mineral $\mathrm{N}$ in the soils caused by low mineralization rates of organic $\mathrm{C}$ and $\mathrm{N}$. As shown in Fig. 2, compared to other seasons, TC and TN in different coastal marsh soils $(0-10,10-20 \mathrm{~cm})$ were lower in summer and $\mathrm{NH}_{4}{ }^{+}-\mathrm{N}$ were lower during spring and summer, indicating that the shortage of $\mathrm{C}$ and mineral $\mathrm{N}$ during summer was unfavorable for $\mathrm{N}_{2} \mathrm{O}$ production. Chapuis-lardy et al. (2007) also pointed out that $\mathrm{N}_{2} \mathrm{O}$ production seemed to be suppressed by low mineral $\mathrm{N}$ and high moisture contents in soil from analysis a large number of literatures. The weak $\mathrm{N}_{2} \mathrm{O}$ emissions in summer were probably because that the mineral $\mathrm{N}$ was almost used up by plants. This speculation could be supported by the evidence that the biggest biomass 
Table 3 Pearson correlation analysis between $\mathrm{N}_{2} \mathrm{O}$ fluxes and soil substrate

\begin{tabular}{|c|c|c|c|c|c|c|c|c|}
\hline \multirow[t]{2}{*}{ Sites } & \multicolumn{2}{|l|}{$\mathrm{TC}$} & \multicolumn{2}{|l|}{$\mathrm{TN}$} & \multicolumn{2}{|l|}{$\mathrm{NH}_{4}^{+}-\mathrm{N}$} & \multicolumn{2}{|l|}{$\mathrm{NO}_{3}{ }^{-}-\mathrm{N}$} \\
\hline & $0-10 \mathrm{~cm}$ & $10-20 \mathrm{~cm}$ & $0-10 \mathrm{~cm}$ & $10-20 \mathrm{~cm}$ & $0-10 \mathrm{~cm}$ & $10-20 \mathrm{~cm}$ & $0-10 \mathrm{~cm}$ & $10-20 \mathrm{~cm}$ \\
\hline HM & 0.292 & 0.250 & 0.317 & 0.232 & -0.611 & $-0.734^{*}$ & -0.211 & 0.219 \\
\hline MM & 0.198 & -0.310 & 0.230 & -0.020 & -0.079 & -0.059 & 0.369 & -0.194 \\
\hline LM & 0.673 & 0.194 & 0.078 & -0.120 & -0.056 & -0.028 & -0.125 & 0.281 \\
\hline MF & 0.298 & -0.293 & 0.251 & 0.019 & -0.700 & $-0.851^{*}$ & -0.316 & -0.515 \\
\hline
\end{tabular}

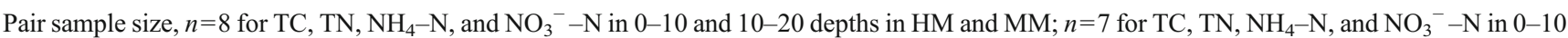
and 10-20 depths in $\mathrm{LM} ; n=6$ for TC, TN, $\mathrm{NH}_{4}-\mathrm{N}$, and $\mathrm{NO}_{3}{ }^{-}-\mathrm{N}$ in $0-10$ and $10-20$ depths in $\mathrm{MF}$

$H M$ high marsh, $M M$ middle marsh, $L M$ low marsh, $M F$ mudflat

${ }^{*} p=0.05$ correlations are significant

accumulation rate (Mou et al. 2010) coincided with the lowest level of $\mathrm{C}$ and mineral $\mathrm{N}$ in the soils (Fig. 2) at this period. This study also showed that high $\mathrm{N}_{2} \mathrm{O}$ emissions occurred during spring and winter (Fig. 4). Many studies have demonstrated that, in the mid-high latitude and high altitude regions, freeze/thaw cycle occurred in late autumn, winter, or early spring was a very important process to increase $\mathrm{N}_{2} \mathrm{O}$ production and emission since it could affect soil physical and biological properties greatly (Teepe et al. 2001; Song et al. 2008). Because the coastal marsh of the Yellow River estuary located in the mid-latitude region $\left(37^{\circ} 35^{\prime} \mathrm{N} \sim 38^{\circ} 12^{\prime} \mathrm{N}\right)$ and the freeze/thaw cycles frequently occurred in topsoil in majority days during spring and winter (frozen depth, $0 \sim 15 \mathrm{~cm}$ ), high $\mathrm{N}_{2} \mathrm{O}$ emissions might be attributed to the frequent freeze/thaw cycles. For one thing, frequent freeze/thaw cycles destroyed the size and stability of soil aggregate (van Bochove et al. 2000), released abundant bioavailable $\mathrm{C}$ and $\mathrm{N}$ (Ludwig et al. 2006), and altered the course and intensity of soil $\mathrm{N}$ transformation (Jarvis et al. 1996), which enhanced the denitrification and $\mathrm{N}_{2} \mathrm{O}$ emission (Priemé and Christensen 2001). For another, since the frozen water film on the soil matrix represented a diffusion barrier which reduced oxygen supply to the microorganisms and partly prevented the release of the $\mathrm{N}_{2} \mathrm{O}$ (Teepe et al. 2001), high emissions occurred due to the quick release of $\mathrm{N}_{2} \mathrm{O}$ trapped by ice layer and/or denitrification during frequent freeze/thaw cycles (Goodroad and Keeney 1984; Teepe et al. 2001). Similar results were drawn by Zhang et al. (2005) and Jiang et al. (2010) who found significant $\mathrm{N}_{2} \mathrm{O}$ emissions from freshwater marsh in the Sanjiang Plain and Alpine meadow in the Qinghai-Tibetin Plateau during the freeze/thaw cycle as the temperature increased.

In this study, the $\mathrm{N}_{2} \mathrm{O}$ emission per sampling month was calculated by the average value and the time in each month and the emissions in absent months were estimated by the average values in the corresponding seasons. Similar method was adopted in some studies to estimate the $\mathrm{N}_{2} \mathrm{O}$ emissions in absent months. Hao et al. (2007) studied the effects of freshwater marshes (Carex lasiocapa marsh and Deyeuxia angustifolia marsh) reclamation on $\mathrm{N}_{2} \mathrm{O}$ fluxes and estimated the emission in absent month (February) by the average value in winter (December and January). Sun et al. (2009) investigated the $\mathrm{N}_{2} \mathrm{O}$ fluxes from Calamagrostis angustifolia marsh in the Sanjiang Plain and estimated the emissions in absent months (February and October) by the average values in winter (December and January) and autumn (September and November), respectively. Since the measurements in this study covered four seasons [spring (April and May), summer (June and July), autumn (September, October, and November), and winter (December)], we considered that based on the average values in the corresponding seasons, the extrapolation of $\mathrm{N}_{2} \mathrm{O}$ emissions in absent months, to a great extent, was valid as the local $\mathrm{N}_{2} \mathrm{O}$ inventory throughout a year was assessed roughly. Although only the roughly accumulated $\mathrm{N}_{2} \mathrm{O}$ emission was given in our study, considering it was estimated for the first time, it still would provide valuable information on understanding the $\mathrm{N}_{2} \mathrm{O}$ inventory in the coastal marsh of the Yellow River estuary. Overall, across all the seasons sampled, the coastal marsh was a net source of $\mathrm{N}_{2} \mathrm{O}\left(113.03 \mathrm{mg} \mathrm{N} \mathrm{N}_{2} \mathrm{O}\right.$ $\mathrm{m}^{-2}$ year ${ }^{-1}$ ) and the $\mathrm{N}_{2} \mathrm{O}$ emissions measured during nongrowing season (spring and winter) comprised the principal part to the total emission $(76.30 \%)$, indicated that the importance of seasonal $\mathrm{N}_{2} \mathrm{O}$ contributions (particularly during nongrowing season) to the estimation of local $\mathrm{N}_{2} \mathrm{O}$ inventory should be paid more attentions. In the following studies, in order to assess the regional budget of $\mathrm{N}_{2} \mathrm{O}$ emissions precisely, measurements should be conducted at all months and the sampling frequency should be increased.

\section{Spatial variations of $\mathrm{N}_{2} \mathrm{O}$ fluxes}

During all times of day and the seasons measured, we found that the physical and chemical parameters of soil differed in their magnitude among the four marshes, and significant differences in TC, TN, and EC in soil were observed $(p<0.05)$. Such differences within the four marshes would be due to the sitespecific conditions (such as topography, slope, hydrology, and species composition) which influence the magnitudes and 
variations of $\mathrm{N}_{2} \mathrm{O}$ at spatial scale (Allen et al. 2007; Hirota et al. 2007). Over all sampling seasons, we observed that $\mathrm{N}_{2} \mathrm{O}$ fluxes from the four marshes were significantly different $(p<0.05)$, in the order of $\mathrm{HM}>\mathrm{MF}>\mathrm{LM}>\mathrm{MM}$ (Fig. 4). Also, a large spatial variation of $\mathrm{N}_{2} \mathrm{O}$ fluxes in the coastal marsh of the Yellow River estuary was observed. The coefficient of variations $(\mathrm{CVs})$ of $\mathrm{N}_{2} \mathrm{O}$ fluxes in the four marshes were $98.47,278.29,164.56$, and $138.12 \%$, respectively, while the value across the coastal marsh was $158.31 \%$, indicating that to assess the regional budget of $\mathrm{N}_{2} \mathrm{O}$ emissions precisely, measurements should be designed at fine scales and the number of spatial replicates should be increased. Previous studies have indicated that temperatures had great influences on $\mathrm{N}_{2} \mathrm{O}$ emissions at spatial scale (Alongi et al. 2005; Gregorich et al. 2006), but this study has drawn a different result. During all the seasons measured, air temperature and ground temperatures did not show significant difference among the four marshes $(p>0.05)$, most correlations between $\mathrm{N}_{2} \mathrm{O}$ fluxes and temperatures in different marshes were not significant $(p>0.05)$ and only few significant positive or negative correlations were found in HM or MM (Table 1). This indicated that the function of thermal condition might be covered by the interactions of other biotic or abiotic factors (such as moisture, salinity, sediment substrate, and vegetation) though it was considered an important factor affecting $\mathrm{N}_{2} \mathrm{O}$ emission. Although $\mathrm{EC}$ showed significant differences within the four marshes $(p<0.05)$, the correlations between EC and $\mathrm{N}_{2} \mathrm{O}$ emission were not significant $(p>0.05)$ (Table 2). By comparison, soil moisture did not show significant differences among the four marshes $(p>0.05)$, but significant positive correlation between soil moisture (5$10 \mathrm{~cm})$ and $\mathrm{N}_{2} \mathrm{O}$ emission was found in $\mathrm{LM}(p<0.05)$ (Table 2). Generally, both positive and negative impacts of soil moisture (or EC) on $\mathrm{N}_{2} \mathrm{O}$ emissions were observed in coastal marshes (Table 2), which were different with mostly previous studies that $\mathrm{N}_{2} \mathrm{O}$ emissions had negative correlation with moisture (Regina et al. 1996; Wang et al. 2005) or EC (Law et al. 1991; Dalal et al. 2003; Chen et al. 2010). One possible explanation for the positive correlations between $\mathrm{EC}$ and $\mathrm{N}_{2} \mathrm{O}$ emissions was that the salinity in LM and MF was much lower than that in HM and MM (Fig.1c), which might not completely inhibit the activities of nitrifiers and denitrifiers in soil (Lv et al. 2008). The positive correlations between soil moisture and $\mathrm{N}_{2} \mathrm{O}$ emissions might be partly dependent on the fluctuation of soil moisture (or water level) by astronomic tide. As shown in Fig. 5, dissimilar variations of $\mathrm{N}_{2} \mathrm{O}$ emissions and flooding depths in LM and MF were observed. Both LM and MF were found to release $\mathrm{N}_{2} \mathrm{O}$ at 0700 and 0930 hours sampling (before flood), indicating that the proper soil moisture might contribute to a favorable aerobic-anerobic status for $\mathrm{N}_{2} \mathrm{O}$ production. As the flood began at 1200 hours sampling, the $\mathrm{N}_{2} \mathrm{O}$ flux in LM decreased and the value in MF became negative, indicating that the soil moisture in LM and MF might be greatly changed due to the different flooding depths, which produced different impacts on $\mathrm{N}_{2} \mathrm{O}$ emission. When the flooding was deeper at 1430 hours sampling, both LM and MF showed great consumptions, indicating that the tidal inundation produced an unfavorable anaerobic status for $\mathrm{N}_{2} \mathrm{O}$ production and the limited $\mathrm{N}_{2} \mathrm{O}$ emission might be severely prevented by flooding seawater. Similar result was drawn by Zhang et al. (2013) who found that tidal inundation significantly decreased the $\mathrm{N}_{2} \mathrm{O}$ emission in the coastal marsh of the Min River estuary. Although the flooding depth in LM decreased and that in MF increased greatly at 1700 hours sampling, both LM and MF were found to release $\mathrm{N}_{2} \mathrm{O}$ greatly, which was mainly dependent on the $\mathrm{N}_{2} \mathrm{O}$ transportation from surface seawater to the two marshes by tidal fluctuation (Senga et al. 2001; Hirota et al. 2007). In addition, the decrease of flooding depth in LM might cause the dissolved $\mathrm{N}_{2} \mathrm{O}$ in seawater to be released, which partly contributed to the significant $\mathrm{N}_{2} \mathrm{O}$ emission. Similar result was drawn by Hirota et al. (2007) who found that in coastal ecosystems subjected to such short-term fluctuation of water level (or soil moisture) by astronomic tide, the
Fig. 5 Variations of $\mathrm{N}_{2} \mathrm{O}$ flux and flooding depth in low marsh $(L M)$ and mudflat $(M F)$ in September 2010

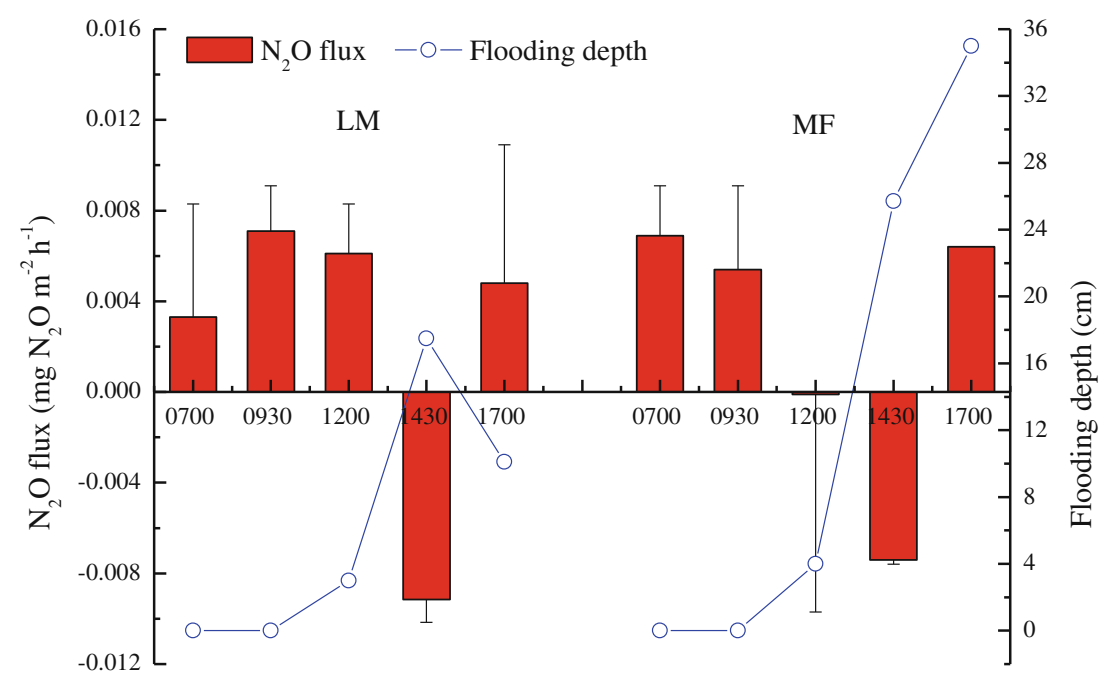


spatial variations in $\mathrm{N}_{2} \mathrm{O}$ flux was controlled by fluctuation of water lever $(r=0.58, p<0.05)$.

Site-level control of $\mathrm{N}_{2} \mathrm{O}$ emission was also attributed to the effects of vegetation and nutrient status. In this study, the plant distributed continuously across the coastal marsh and the plant compositions in the four mashes were different. The coverage and maximum biomass of $S$. salsa-P. australis community (HM) were 1.19- and 1.90-folds and 1.60- and 3.57-folds of $S$. salsa-T. chinensis community(MM) and $S$. salsa community (LM), respectively (Mou 2010; Dong et al. 2010). Also, the presence of $P$. australis, $T$. chinensis, and $S$. salsa had great impacts on $\mathrm{N}_{2} \mathrm{O}$ emission as mentioned previously. These indicated that the vegetations across the coastal marsh might play an important role in controlling the $\mathrm{N}_{2} \mathrm{O}$ emissions at spatial scale. Although both TC and TN in soils showed significant differences among the four marshes $(p<0.05)$, lacks of correlations between $\mathrm{N}_{2} \mathrm{O}$ fluxes and TC (or TN) were observed ( $p>0.05$ ) (Table 3). By comparison, although both $\mathrm{NH}_{4}{ }^{+}-\mathrm{N}$ and $\mathrm{NO}_{3}{ }^{-}-\mathrm{N}$ had no significant differences within the four marshes $(p>0.05)$, significant correlations between $\mathrm{N}_{2} \mathrm{O}$ fluxes and $\mathrm{NH}_{4}{ }^{+}-\mathrm{N}$ could be observed in subsurface soil of HM and MF $(p<0.05)$ (Table 3$)$. C and $\mathrm{N}$ were very important substrates for $\mathrm{N}_{2} \mathrm{O}$ production (participated in nitrification and denitrification processes) (Tauchnitz et al. 2008) and they generally influenced $\mathrm{N}_{2} \mathrm{O}$ emissions by $\mathrm{C} / \mathrm{N}$ regulations and interactions with other abiotic variables (Blackwell et al. 2010). In this study, negative correlations between $\mathrm{N}_{2} \mathrm{O}$ emissions and nutrient variables were generally observed in the four marshes (Table 3), which was different with mostly previous studies (Aelion et al. 1997; MuñozHincapié et al. 2002; Chen et al. 2010). One possible reason was related to the interaction of vegetation and microorganism (nitrifiers and denitrifiers) during $\mathrm{N}_{2} \mathrm{O}$ production ( $\mathrm{Li}$ et al. 2002). $\mathrm{N}_{2} \mathrm{O}$ production might be greatly inhibited as the available $\mathrm{N}$ was significantly competed by both vegetations and microorganisms in $S$. salsa-P. australis community, $S$. salsa-T. chinensis community, and $S$. salsa community, which partly contributed to the difference of $\mathrm{N}_{2} \mathrm{O}$ emissions at spatial scale. Since there was no vegetation in $\mathrm{MF}$, the negative correlations between $\mathrm{N}_{2} \mathrm{O}$ emissions and nutrient variables were possibly correlated with the high soil moisture (Fig.1b). Under high moisture condition, the $\mathrm{NO}_{3}{ }^{-}-\mathrm{N}$ in topsoil could be easily transferred to the deep soil layer, which decreased the chance to participate in nitrification and denitrification processes. As shown in Fig. $2 \mathrm{~d}$, the $\mathrm{NO}_{3}{ }^{-}-\mathrm{N}$ in topsoil of MF was very low, which could partly explain the negative influences on $\mathrm{N}_{2} \mathrm{O}$ production and emission.

Comparisons with other measurements and potential of $\mathrm{N}$ loading on $\mathrm{N}_{2} \mathrm{O}$ emissions

Previous studies that have examined the release of $\mathrm{N}_{2} \mathrm{O}$ from different coastal marshes and mangrove swamps reported about the fluxes in the range of -0.1298 to $0.1953 \mathrm{mg} \mathrm{N}_{2} \mathrm{O}$ $\mathrm{m}^{-2} \mathrm{~h}^{-1}$ (Alongi et al. 2005; Xie et al. 2011) (Table 4). The magnitudes of $\mathrm{N}_{2} \mathrm{O}$ fluxes determined in this study $\left(-0.0051 \sim 0.0805 \mathrm{mg} \mathrm{N}_{2} \mathrm{O} \mathrm{m}^{-2} \mathrm{~h}^{-1}\right)$ were in the range, which were higher than those from coastal marshes in the Yangtze River estuary $\left(-0.0096 \sim 0.0079 \mathrm{mg} \mathrm{N}_{2} \mathrm{O} \mathrm{m}^{-2} \mathrm{~h}^{-1}\right)$ and the Min River estuary (0.0037 0.0157 $\left.\mathrm{mg} \mathrm{N}_{2} \mathrm{O} \mathrm{m}{ }^{-2} \mathrm{~h}^{-1}\right)$, and mangrove swamps in the Moreton Bay $\left(-0.002 \sim 0.014 \mathrm{mg} \mathrm{N}_{2} \mathrm{O}\right.$ $\mathrm{m}^{-2} \mathrm{~h}^{-1}$ ), but matched emissions recorded at coastal tundra marshes in the eastern Antarctica $\left(-0.0206 \sim 0.0856 \mathrm{mg} \mathrm{N}_{2} \mathrm{O}\right.$ $\mathrm{m}^{-2} \mathrm{~h}^{-1}$ ), coastal marshes in the coastal lagoon of Lake Nakaumi (-0.01 0.06 $\left.\mathrm{mg} \mathrm{N}_{2} \mathrm{O} \mathrm{m} \mathrm{m}^{-2} \mathrm{~h}^{-1}\right)$ and mangrove swamps in the Brisbane River $\left(-0.004 \sim 0.065 \mathrm{mg} \mathrm{N}_{2} \mathrm{O}\right.$ $\left.\mathrm{m}^{-2} \mathrm{~h}^{-1}\right)$ and Magueyes Island (0.0022 0.0616 $\mathrm{mg} \mathrm{N}_{2} \mathrm{O}$ $\mathrm{m}^{-2} \mathrm{~h}^{-1}$ ) (Table 4).

In this paper, we found that the coastal marsh acted as a $\mathrm{N}_{2} \mathrm{O}$ source (cumulative $\mathrm{N}_{2} \mathrm{O}$ emission throughout a year was $113.03 \mathrm{mg} \mathrm{N}_{2} \mathrm{O} \mathrm{m}^{-2}$ ) in the present $\mathrm{N}$ loading of the Yellow River estuary. Numerous studies have demonstrated that exogenous $\mathrm{N}$ generally had great stimulatory effects on the production and emission of $\mathrm{N}_{2} \mathrm{O}$ (Lee et al. 1997; MuñozHincapié et al. 2002; Liikanen et al. 2003; Song et al. 2006; Zhang et al. 2007; Stadmark and Leonardson 2007; Li et al. 2009, 2010; Zhang et al. 2012, 2013), but the promoted magnitude of $\mathrm{N}_{2} \mathrm{O}$ flux to $\mathrm{N}$ enrichment varied due to the $\mathrm{N}$ addition level (Song et al. 2006; Zhang et al. 2007; Li et al. 2009, 2010; Zhang et al. 2012; Mou et al. 2012) and $\mathrm{N}$ forms $\left(\mathrm{NH}_{4}{ }^{+}-\mathrm{N}\right.$ and $\mathrm{NO}_{3}{ }^{-}-\mathrm{N}$ ) (Smith et al. 1983; Lindau and DeLaune 1991; Cartaxana and Lloyd 1999; MuñozHincapié et al. 2002; Wan et al. 2009). Wang (2011) studied the responses of $\mathrm{N}$ enrichment $\left(\mathrm{NH}_{4}{ }^{+}-\mathrm{N}\right)$ on the $\mathrm{N}_{2} \mathrm{O}$ production of coastal marsh soil in the Yellow River estuary, and found that the additions of $\mathrm{NH}_{4}{ }^{+}-\mathrm{N}$ had great stimulation on $\mathrm{N}_{2} \mathrm{O}$ production, with approximately $1.93 \sim 3.71$-folds of $\mathrm{N}_{2} \mathrm{O}$ production being observed with increasing $\mathrm{NH}_{4}{ }^{+}-\mathrm{N}$ addition. Denitrification was the most important process for $\mathrm{N}_{2} \mathrm{O}$ production and its contribution to total $\mathrm{N}_{2} \mathrm{O}$ production would also be elevated with increasing $\mathrm{NH}_{4}{ }^{+}-\mathrm{N}$ addition (Wang 2011). The increase in $\mathrm{N}_{2} \mathrm{O}$ emission under $\mathrm{N}$ addition was probably caused by the enhancement of both nitrifiers and denitrifiers activities (Wrage et al. 2004). At present, the exogenous $\mathrm{N}$ loading $\left(\mathrm{NH}_{4}{ }^{+}-\mathrm{N}\right.$ is dominated) of the Yellow River estuary is increasing due to human activities (State Oceanic Administration of China 2013). Since N is a very limited nutrient in the coastal marshes of the Yellow River estuary (Mou 2010), increases in exogenous N loading to estuarine and coastal marshes will stimulate microbial processes and $\mathrm{N}_{2} \mathrm{O}$ emission. As shown in Table 4, the mean $\mathrm{N}_{2} \mathrm{O}$ flux from Futian mangrove $\left(0.7572 \mathrm{mg} \mathrm{N}_{2} \mathrm{O} \mathrm{m}^{-2} \mathrm{~h}^{-1}\right)$ and the maximum $\mathrm{N}_{2} \mathrm{O}$ emission from Mai Po mangrove $(0.4176 \mathrm{mg}$ $\mathrm{N}_{2} \mathrm{O} \mathrm{m}^{-2} \mathrm{~h}^{-1}$ ) in the Deep Bay region of South China recorded by Chen et al. (2010) were 9.41 and 5.19 times greater than the maximum $\mathrm{N}_{2} \mathrm{O}$ emission reported by our study, and the reason 


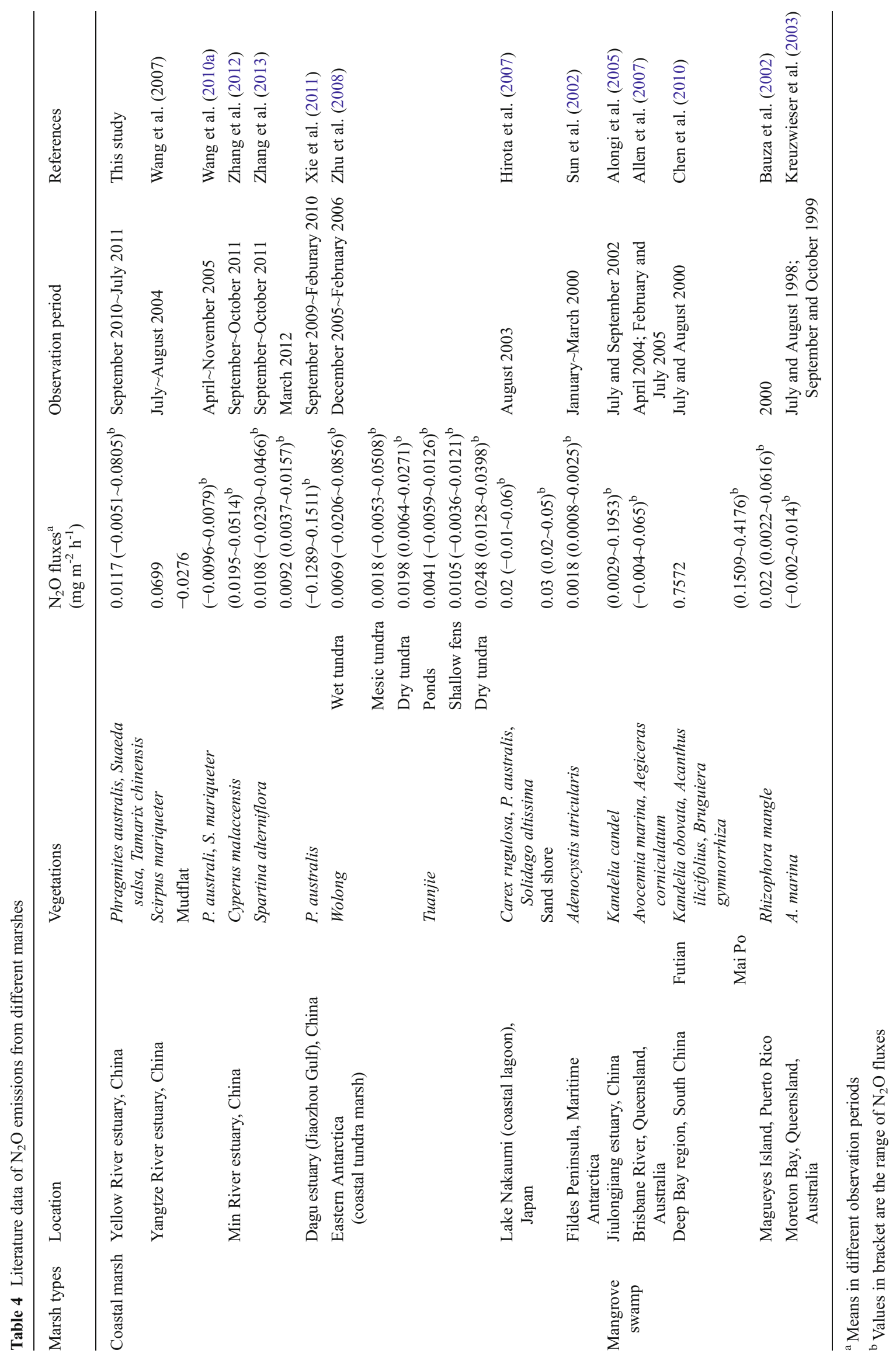


was probably dependent on the higher nutrient loadings of the Deep Bay region compared to the Yellow River estuary. According to the Ocean Environmental Quality Communique of China in 2012, approximately $4.22 \times 10^{4}$ tons of nutrients and $4.39 \times 10^{5}$ tons of OM were discharged into Bohai Sea by Yellow River, while approximately $6.42 \times 10^{5}$ tons of nutrients and $4.65 \times 10^{5}$ tons of OM were imported into Deep Bay region by Pearl River (State Oceanic Administration of China 2013). Because the Futian and Mai Po mangroves were located in inner Deep Bay receiving discharges from the Pearl River Delta and nearby polluted rivers in Shenzhen and Hong Kong (Ong Che 1999), significantly higher fluxes of $\mathrm{N}_{2} \mathrm{O}$ were mainly related to the high nutrient inputs from the polluted rivers that flooded into Deep Bay, such as Pearl River (Chen et al. 2010).

Based on the above analysis, we concluded that the $\mathrm{N}_{2} \mathrm{O}$ emission in the future will be enhanced with increasing $\mathrm{N}$ loading to the Yellow River estuary (especially $\mathrm{NH}_{4}{ }^{+}-\mathrm{N}$ is the major pollutant) and denitrification will play a very important role in contributing the total $\mathrm{N}_{2} \mathrm{O}$ emission. With increasing $\mathrm{N}$ loading, the magnitude of $\mathrm{N}_{2} \mathrm{O}$ emission in the Yellow River estuary should be paid more attention as the annual or local $\mathrm{N}_{2} \mathrm{O}$ inventory was assessed accurately.

Acknowledgments The authors would like to acknowledge the two anonymous reviewers for their constructive comments on this paper. This study was financially supported by the Strategy Guidance Program of the Chinese Academy of Sciences (no. XD05030404), the "1-3-5" Strategy Plan Program of the Yantai Institute of Coastal Zone Research of the Chinese Academy of Sciences (no. Y254021031), the National Nature Science Foundation of China (no. 41171424), the Key Program of Natural Science Foundation of Shandong Province (no. ZR2010DZ001), the Talents Program of the Youth Innovation Promotion Association, Chinese Academy of Sciences (no. Y129091041), and the Ocean Public Welfare Scientific Research Project, State Oceanic Administration, People's Republic of China (no. 2012418008-3).

Open Access This article is distributed under the terms of the Creative Commons Attribution License which permits any use, distribution, and reproduction in any medium, provided the original author(s) and the source are credited.

\section{References}

Aelion CM, Shaw JN, Wahl M (1997) Impact of suburbanization on ground water quality and denitrification in coastal aquifer sediments. J Exp Mar Biol Ecol 213:31-51

Allen DE, Dalal RC, Rennenberg H, Meyer RL, Reeves S, Schmidt S (2007) Spatial and temporal variation of nitrous oxide and methane flux between subtropical mangrove sediments and the atmosphere. Soil Biol Biochem 39:622-631

Alongi DM, Pfitzner J, Trott LA, Tirendi F, Dixon P, Klumpp DW (2005) Rapid sediment accumulation and microbial mineralization in forests of the mangrove Kandelia candel in the Jiulongjiang Estuary, China. Estuar Coast Shelf S 63:605-618

Amouroux D, Roberts G, Rapsomanikis S, Andreae MO (2002) Biogenic gas $\left(\mathrm{CH}_{4}, \mathrm{~N}_{2} \mathrm{O}\right.$, DMS $)$ emission to the atmosphere from near-shore and shelf waters of the North-western Black Sea. Estuar Coast Shelf S 54(3):575-587

Bauza JF, Morell JM, Corredor JE (2002) Biogeochemistry of nitrous oxide production in the red mangrove (Rhizophora mangle) forest sediments. Estuar Coast Shelf S 55:697-704

Blackwell MSA, Yamulki S, Bol R (2010) Nitrous oxide production and denitrification rates in estuarine intertidal saltmarsh and managed realignment zones. Estuar Coast Shelf S 87:591-600

Cartaxana P, Lloyd D (1999) $\mathrm{N}_{2}, \mathrm{~N}_{2} \mathrm{O}$ and $\mathrm{O}_{2}$ profiles in a tagus estuary salt marsh. Estuar Coast Shelf S 48(6):751-756

Chapuis-Lardy L, Wrage N, Metay A, Chotte JL, Bernoux M (2007) Soils, a sink for $\mathrm{N}_{2} \mathrm{O}$ ? A review. Global Change Biol 13:1-177

Chen GC, Tam NFY, Ye Y (2010) Summer fluxes of atmospheric greenhouse gases $\mathrm{N}_{2} \mathrm{O}, \mathrm{CH}_{4}$ and $\mathrm{CO}_{2}$ from mangrove soil in South China. Sci Total Environ 408:2761-2767

Cheng WX (2009) Rhizosphere priming effect: its functional relationships with microbial turnover, evapotranspiration, and $\mathrm{C}-\mathrm{N}$ budgets. Soil Biol Biochem 41:1795-1801

Conrad R (1996) Soil microorganisms as controllers of atmospheric trace gases $\left(\mathrm{H}_{2}, \mathrm{CO}, \mathrm{CH}_{4}, \mathrm{OCS}, \mathrm{N}_{2} \mathrm{O}\right.$, and $\left.\mathrm{NO}\right)$. Microbiol Rev 60:609 640

Crutzen PJ, Ehhalt DH (1977) Effects of nitrogen fertilizers and combustion on the stratospheric ozone layer. Ambio 6:112-117

Cui BS, Yang QC, Yang ZF, Zhang KJ (2009) Evaluating the ecological performance of wetland restoration in the Yellow River Delta, China. Ecol Eng 35:1090-1103

Dalal RC, Wang WJ, Robertson GP, Parton WJ (2003) Nitrous oxide emission from Australian agricultural lands and mitigation options: a review. Aust J Soil Res 41:165-195

Dong HF, Yu JB, Sun ZG, Mou XJ, Chen XB, Mao PL, Wu CF, Guan B (2010) Spatial distribution characteristics of organic carbon in the soil-plant systems in the Yellow River estuary tidal flat wetland. Environ Sci 31(6):1594-1599

Ganguly D, Dey M, Mandal SK, De TK, Jana TK (2008) Energy dynamics and its implication to biosphere-atmosphere exchange of $\mathrm{CO}_{2}, \mathrm{H}_{2} \mathrm{O}$ and $\mathrm{CH}_{4}$ in a tropical mangrove forest canopy. Atmos Environ 42:4172-4184

Ge LP, Zhang H (2011) Characteristics of soil enzymatic activities and relationship with the main nutrient in the rhizosphere of four littoral halophytes. Ecol Environ Sci 20(2):270-275

Goodroad LL, Keeney DR (1984) Nitrous oxide emissions from soils during thawing. Can J Soil Sci 64:187-194

Gregorich EG, Hopkins DW, Elberling B, Sparrow AD, Novis P, Greefield LG, Rochette $\mathrm{P}$ (2006) Emission of $\mathrm{CO}_{2}, \mathrm{CH}_{4}$ and $\mathrm{N}_{2} \mathrm{O}$ from lakeshore soils in an Antarctic dry valley. Soil Biol Biochem 38:3120-3129

Han N, Shao Q, Lu CM, Wang BS (2005) The leaf tonoplast V-H ${ }^{+}$-ATPase activity of $\mathrm{a}_{3}$ halophyte Suaeda salsa is enhanced by salt stress in a Ca-dependent mode. J Plant Physiol 162:267-274

Hao QJ, Wang YS, Song CC, Jiang CS (2007) Effects of marsh reclamation on methane and nitrous oxide emissions. Acta Ecol Sin 27(8):3417-3426

Hirota M, Senga Y, Seike Y, Nohara S, Kunii H (2007) Fluxes of carbon dioxide, methane and nitrous oxide in two contrastive fringing zones of coastal lagoon, Lake Nakaumi, Japan. Chemosphere 68:597-603

IPCC (2007) Changes in atmospheric constituents and in radioactive forcing. In: Climate change: the physical science basis. Contribution of Working Group I to the Fourth Assessment Report of the Intergovernmental Panel on Climate Change. Cambridge University Press, Cambridge

Jarvis SC, Stockdale EA, Shepherd MA, Powlson DS (1996) Nitrogen mineralization in temperate agricultural soils: processes and measurement. Adv Agron 57:187-235

Jiang CM, Yu GY, Fang HJ, Cao GM, Li YN (2010) Short-term effect of increasing nitrogen deposition on $\mathrm{CO}_{2}, \mathrm{CH}_{4}$ and $\mathrm{N}_{2} \mathrm{O}$ fluxes in an alpine meadow on the Qinghai-Tibetan Plateau, China. Atmos Environ 44:2920-2926 
Kong Y, Wang Z, Gu YJ, Wang YX (2008) Research progress on aerenchyma formation in plant roots. Chin Bull Bot 25(2):248-253

Kreuzwieser J, Buchholz J, Rennenberg H (2003) Emission of methane and nitrous oxide by Australian mangrove ecosystems. Plant Biol 5:423-431

Law CS, Rees AP, Owens NJP (1991) Temporal variability of denitrification in estuarine sediments. Estuar Coast Shelf S 33:37-56

Lee RY, Joye SB, Roberts BJ, Valiela I (1997) Release of $\mathrm{N}_{2}$ and $\mathrm{N}_{2} \mathrm{O}$ from salt-marsh sediments subject to different land-derived nitrogen loads. Biol Bull 193(2):292-293

Li J, Yu Q, Tong XJ (2002) Vegetation - an important source of atmospheric $\mathrm{N}_{2} \mathrm{O}$. Earth Sci Front 9(1):112

Li YC, Song CC, Hou CC, Song YY (2010) Dynamics of $\mathrm{N}_{2} \mathrm{O}$ emission and carbon mineralization to exogenous nitrogen input in meadow marsh soil. J Soil Water Conserv 24(4):140-147

Li YC, Song CC, Liu DY, Wang L (2009) Denitrification loss and $\mathrm{N}_{2} \mathrm{O}$ emissions from different nitrogen inputs in meadow marsh soil. Res Environ Sci 22(9):1103-1107

Li YF, Huang YL, Li SK (1991) A primarily analysis on the coastal physiognomy and deposition of the modern Yellow River Delta. Acta Oceanol Sin 13(5):662-671

Liikanen A, Ratilainen E, Saarnio S, Alm J, Martikainen PJ, Silvola J (2003) Greenhouse gas dynamics in boreal, littoral sediments under raised $\mathrm{CO}_{2}$ and nitrogen supply. Freshwater Biol 48(3):500-511

Lindau CW, DeLaune RD (1991) Dinitrogen and nitrous oxide emission and entrapment in Spartina alterniflora saltmarsh soils following addition of N-15 labelled ammonium and nitrate. Estuar Coast Shelf S 32(2):161-172

Ling Y, Ding H, Xu YT (2008) Effects of reed roots on rhizosphere microbes in constructed wetland. Syst Sci Compre Stud Agr 24(2):214-216

Ludwig B, Teepe R, Lopes de Gerenyu V, Flessa $\mathrm{H}$ (2006) $\mathrm{CO}_{2}$ and $\mathrm{N}_{2} \mathrm{O}$ emissions from gleyic soils in the Russian tundra and a German forest during freeze-thaw periods - a microcosm study. Soil Biol Biochem 38:3516-3519

Lv YH, Bai H, Jiang Y, Yu JH (2008) Study of nitrification activity and impact factors of wetland in Yellow River Delta. Transaction of Oceanol Limno 2:61-66

Magalhães C, Costa J, Teixeira C, Bordalo AA (2007) Impact of trace metals on denitrification in estuarine sediments of the Douro River estuary, Portugal. Mar Chem 107:332-341

Moseman-Valtierra S, Gonzalez R, Kroeger KD, Tang JW, Chao WC, Crusius J, Bratton J, Green A, Shelton J (2011) Short-term nitrogen additions can shift a coastal wetland from a sink to a source of $\mathrm{N}_{2} \mathrm{O}$. Atmos Environ 45:4390-4397

Mosier AR (1998) Soil processes and global change. Biol Fert Soils $27: 221-229$

Mou XJ (2010) Study on the nitrogen biological cycling characteristics and cycling model of tidal wetland ecosystem in Yellow River estuary. Masters Degree Dissertation, Yantai Institute of Coastal Zone Research, Chinese Academy of Sciences, Yantai

Mou XJ, Liu XT, Tong C, Sun ZG (2012) Short-term effects of exogenous nitrogen on $\mathrm{CH}_{4}$ and $\mathrm{N}_{2} \mathrm{O}$ effluxes from Cyperus malaccensis marsh in the Min River estuary. Environ Sci 33(7):2482-2489

Mou XJ, Sun ZG, Wang LL, Dong HF (2010) Characteristics of nitrogen accumulation and allocation of Suaeda salsa in different growth conditions of intertidal zone in Yellow River estuary. Wetland Sci $8(1): 57-66$

Muñoz-Hincapié M, Morell JM, Corredor JE (2002) Increase of nitrous oxide flux to the atmosphere upon nitrogen addition to red mangroves sediments. Mar Pollut Bull 44:992-996

Ong Che RG (1999) Concentration of seven heavy metals in soils and mangrove root samples from Mai Po, Hong Kong. Mar Pollut Bull 39:269-79

Priemé A, Christensen S (2001) Natural perturbations, drying-wetting and freezing-thawing cycles, and the emission of nitrous oxide, carbon dioxide and methane from farmed organic soils. Soil Biol Biochem 33:2083-2091

Purvaja R, Ramesh R (2001) Natural and anthropogenic methane emission from coastal wetlands of South India. Environ Manage 27:547557

Regina K, Nykänen H, Silvola J, Martikainen PJ (1996) Fluxes of nitrous oxide from boreal peatlands as affected by peatland type, water table level and nitrification capacity. Biogeochemistry 35:401-418

Seitzinger SP, Kroeze C (1998) Global distribution of nitrous oxide production and $\mathrm{N}$ inputs in freshwater and coastal marine ecosystems. Global Biogeochem Cy 12:93-113

Senga Y, Seike Y, Mchida K, Fujianaga K, Okumura M (2001) Nitrous oxide in Lake Shinji and Nakaumi, Japan. Limnology 2:129-136

Shingo U, Chun-sim UG, Takahito Y (2000) Dynamics of dissolved $\mathrm{O}_{2}$ $\mathrm{CO}_{2}, \mathrm{CH}_{4}$ and $\mathrm{N}_{2} \mathrm{O}$ in a tropical coastal swamp in southern Thailand. Biogeochemistry 49:191-215

Smith CJ, DeLaune RD, Patrick WH Jr (1983) Nitrous oxide emission from Gulf Coast wetlands. Geochim Cosmochim Ac 47(10):18051814

Song CC, Zhang JB, Wang YY, Wang YS, Zhao ZC (2008) Emission of $\mathrm{CO}_{2}, \mathrm{CH}_{4}$ and $\mathrm{N}_{2} \mathrm{O}$ from freshwater marsh in Northeast of China. $\mathrm{J}$ Environ Manage 88:428-436

Song CC, Zhang LH, Wang YY, Zhao ZC (2006) Annual dynamics of $\mathrm{CO}_{2}, \mathrm{CH}_{4}, \mathrm{~N}_{2} \mathrm{O}$ emissions from freshwater marshes and affected by nitrogen fertilization. Environ Sci 27(12):2369-2375

Søvik AK, Kløve B (2007) Emission of $\mathrm{N}_{2} \mathrm{O}$ and $\mathrm{CH}_{4}$ from a constructed wetland in southeastern Norway. Sci Total Environ 380:28-37

Stadmark J, Leonardson L (2007) Greenhouse gas production in a pond sediment: Effects of temperature, nitrate, acetate and season. Sci Total Environ 387(1-3):194-205

State Oceanic Administration of China (2013) Ocean Environmental Quality Communique of China in 2012. (http://www.coi.gov.cn/ gongbao/nrhuanjing/nr2012/201304/t20130401_26413.html). Accessed 10 February 2013

Sun LG, Zhu RB, Xie ZQ, Xing GX (2002) Emissions of nitrous oxide and methane from Antarctic Tundra: role of penguin dropping deposition. Atmos Environ 36:4977-4982

Sun ZG, Liu JS, Yang JS, Mou XJ, Wang LL (2009) $\mathrm{N}_{2} \mathrm{O}$ flux characteristics and emission contributions of Calamagrostis angustiflolia wetland during growth and non-growth seasons. Acta Pratacul Sin 18(6):241-247

Tauchnitz N, Brumme R, Bernsdorf S, Meissner R (2008) Nitrous oxide and methane fluxes of a pristine slope mire in the German National Park Harz Mountains. Plant Soil 303:131-138

Teepe R, Brumme R, Beese F (2001) Nitrous oxide emissions from soil during freezing and thawing periods. Soil Biol Biochem 33:1269-1275

Teiter S, Mander Ü (2005) Emission of $\mathrm{N}_{2} \mathrm{O}, \mathrm{N}_{2}, \mathrm{CH}_{4}$, and $\mathrm{CO}_{2}$ from constructed wetlands from wastewater treatment and from riparian buffer zones. Ecol Eng 25:528-542

Tian JY, Wang XF, Cai XJ (2005) Protection and restoration technique of wetland ecosystem in Yellow River Delta. China Ocean University Press, Qingdao

van Bochove E, Prévost D, Pelletier F (2000) Effects of freeze-thraw and soil structure on nitrous oxide produced in a clay soil. Soil Sci Soc Am J 64:1638-1643

Wan XH, Kuang SF, Zhou HD (2009) Research of exogenous nitrogen input on $\mathrm{N}_{2} \mathrm{O}$ fluxes in constructed wetland. J China Inst Water Resour Hydropower Res 7(4):264-269

Wang DQ, Chen ZL, Wang J, Xu SY, Yang HX, Chen H, Yang LY, Hu LZ (2007a) Summer-time denitrification and nitrous oxide exchange in the intertidal zone of the Yangtze Estuary. Estuar Coast Shelf S 73:43-53

Wang DQ, Chen ZL, Wang J, Xu SY, Yang HX, Chen H, Yang YL (2007b) Fluxes of $\mathrm{CH}_{4}, \mathrm{CO}_{2}$ and $\mathrm{N}_{2} \mathrm{O}$ fluxes from Yangtze estuary intertidal flat in summer season. Geochimica 36(1):78-88 
Wang DQ, Chen ZL, Wang J, Xu SY, Yang HX, Chen H, Yang LY, Hu LZ (2006) Denitrification, nitrous oxide emission and adsorption in intertidal flat, Yangtze estuary, in summer. Geochimica 35(3):271279

Wang LF, Cai ZC, Yang LF, Meng L (2005) Effect of disturbance and glucose addition on nitrous oxide and carbon dioxide emissions from a paddy soil. Soil Till Res 82:185-194

Wang LL (2011) Study on the nitrous oxide emission rule and influence mechanism of tidal wetland ecosystem in the Yellow River estuary. Masters Degree Dissertation, Yantai Institute of Coastal Zone Research, Chinese Academy of Sciences, Yantai

Wang Q, Liu M, Hou LJ, Cheng SB (2010a) Characteristics and influencing factors of $\mathrm{CO}_{2}, \mathrm{CH}_{4}$ and $\mathrm{N}_{2} \mathrm{O}$ emissions from Chongming eastern tidal flat wetland. Geogr Res 29(5):935-946

Wang ZY, Zhao FF, Zhang BG, Zhang L, Li FM, Gao DM, Luo XX (2010b) Rhizosphere effect of three halophytes in the Yellow River Delta on nitrogen and phosphorus. Environ Sci Technol 33(10):33-38

Whalen SC (2005) Biogeochemistry of methane exchange between natural wetlands and the atmosphere. Environ Eng Sci 22:7394

World Meteorological Organization (2011) WMO Greenhouse Gas Bulletin No.7 (21 November 2011). http:/www.wmo.int/pages/ prog/arep/gaw/ghg/documents/GHGbulletin_7_en.pdf. Accessed 15 January 2013

Wrage N, Velthof GL, Laanbroek HJ, Oenema O (2004) Nitrous oxide production in grassland soils: assessing the contribution of nitrifier denitrification. Soil Biol Biochem 36(2):229-236
Xie WX, Zhao QS, Zhang F, Ma XF (2011) Characteristics of $\mathrm{N}_{2} \mathrm{O}$ flux in estuary wetland of Jiaozhou Bay in autumn and winter. Sci Geogra Sin 31(4):464-469

Xu XG, Guo HH, Chen XL, Lin HP, Du QL (2002) A multi-scale study on land use and land cover quality change: the case of the Yellow River Delta in China. GeoJournal 56:177-183

Yang HX, Wang DQ, Chen ZL, Xu SY (2006) Elementary research on green-house gas emissions in Chongming east intertidal flat of the Changjiang estuary. Mar Environ Sci 25:20-23

Yang P, Tong C, He QH, Huang JF (2012) Diurnal variations of greenhouse gas gluxes at the water-air interface of aquaculture ponds in the Min River estuary. Environ Sci 33(12):4194-4204

Zhang JB, Song CC, Yang WY (2005) Cold season $\mathrm{CH}_{4}, \mathrm{CO}_{2}$ and $\mathrm{N}_{2} \mathrm{O}$ fluxes from freshwater marshes in northeast China. Chemosphere 59(11):1703-1705

Zhang LH, Song CC, Wang DX, Wang YY (2007) Effects of exogenous nitrogen on freshwater marsh plant growth and $\mathrm{N}_{2} \mathrm{O}$ fluxes in Sanjiang Plain, Northeast China. Atmos Environ 41(5):1080-1090

Zhang YX, Zeng CS, Huang JF, Wang WQ, Tong C (2013) Effects of human-caused disturbance on nitrous oxide flux from Cyperus malaccensis marsh in the Minjiang River estuary. China Environ Sci 33(1):138-146

Zhang YX, Zeng CS, Tong C, Wang WQ, Huang JF, He QH (2012) Tidal action and tread affecting nitrous oxide fluxes in intertidal Cyperus malaccensis var. brevifolius marsh. Ecol Environ Sci 21(4):641-646

Zhu RB, Liu YS, Ma J, Xu H, Sun LG (2008) Nitrous oxide flux to the atmosphere from two coastal tundra wetlands in eastern Antarctica. Atmos Environ 42:2437-2447 